
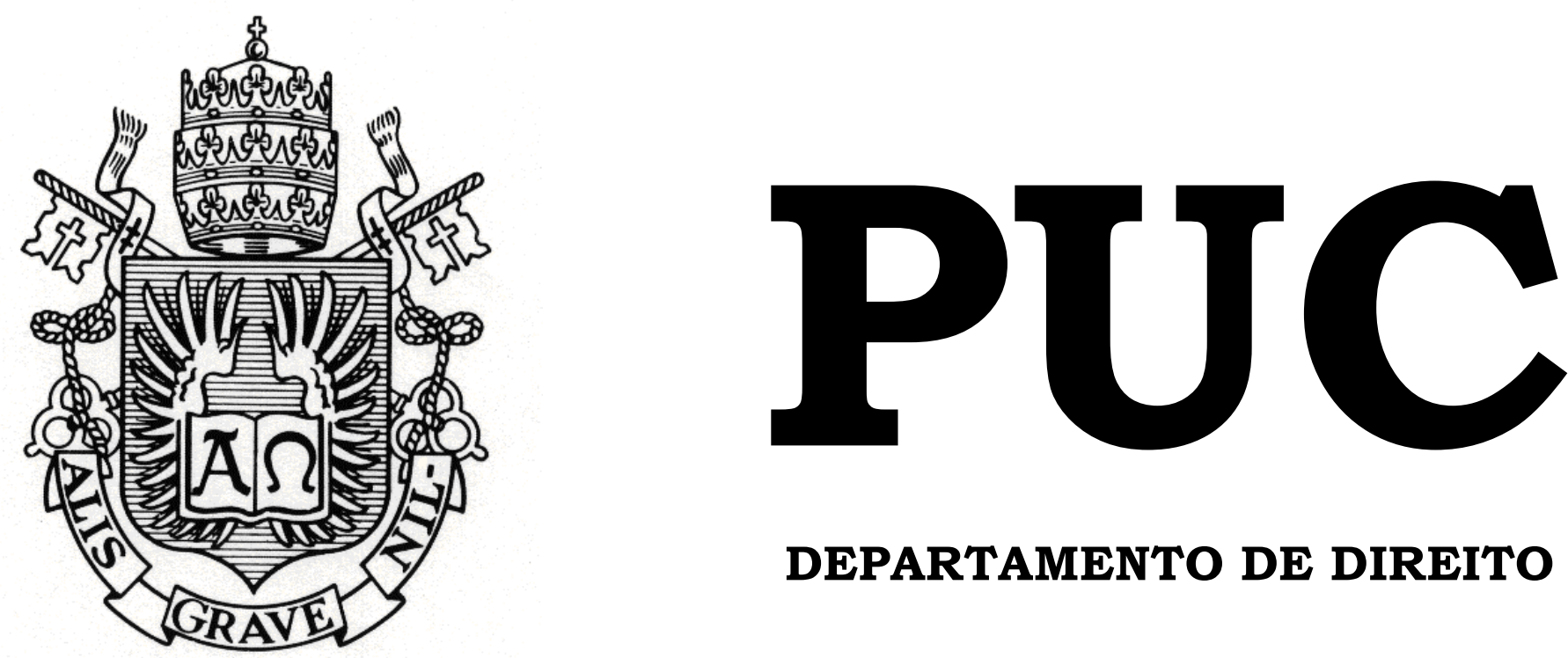

DEPARTAMENTO DE DIREITO

\title{
PARTICIPAÇÃO E DEFESA DO MEIO AMBIENTE: AS AUDIÊNCIAS PÚBLICAS EM LICENCIAMENTOS AMBIENTAIS NO RIO DE JANEIRO
}

\author{
por \\ MARIANA BULHÕES FREIRE DE CARVALHO \\ ORIENTADOR(A): Virginia Totti Guimarães \\ 2013.1
}

PONTIFÍCIA UNIVERSIDADE CATÓLICA DO RIO DE JANEIRO

RUA MARQUÊS DE SÃO VICENTE, 225 - CEP 22453-900

RIO DE JANEIRO - BRASIL 


\section{PARTICIPAÇÃO E DEFESA DO MEIO AMBIENTE: AS AUDIÊNCIAS PÚBLICAS EM LICENCIAMENTOS AMBIENTAIS NO RIO DE JANEIRO}

por

MARIANA BULHÕES FREIRE DE CARVALHO

Monografia apresentada ao Departamento de Direito da Pontifícia Universidade Católica do Rio de Janeiro (PUC-Rio) para a obtenção do Título de Bacharel em Direito.

Orientador(a): Virginia Totti Guimarães

2013.1 


\section{Dedicatória}

À Cidade do Rio de Janeiro e a todos que nela atuam, com ética e amor, para protegê-la. 


\section{Agradecimentos}

À minha família por sempre me apoiar e por ter me proporcionado uma graduação de tão alto nível.

Á todos do Nima Jur que, durante todos esses anos, contribuíram para o meu encanto pelo Direito Ambiental. Em especial, agradeço imensamente ao Professor Fernando Cavalcanti Walcacer, a Professora Danielle de Andrade Moreira e a minha orientadora, Professora Virgínia Totti Guimarães, pela dedicação e disponibilidade em todos os momentos - todos profissionais admiráveis e amigos queridos.

Á todos os amigos que, direta ou indiretamente, colaboraram para este trabalho. 
Resumo: A participação social e o acesso à informação em matéria ambiental são amplamente reconhecidos no ordenamento jurídico nacional e internacional como fundamentais para o desenvolvimento de políticas ambientais democráticas. Isso porque, a exigência da participação popular decorre da própria natureza coletiva do bem ambiental, difuso, pertencente a todos os cidadãos destas e das futuras gerações.

A audiência pública no bojo do licenciamento ambiental é instrumento crucial que possibilita a influência direta da população na decisão pública sobre a viabilidade de empreendimentos que causam impactos no meio ambiente.

Neste trabalho os principais objetivos são ressaltar a relevância da participação popular e do acesso à informação para as audiências públicas, e criticar a manipulação deste instituto - ou seu emprego esvaziado como se fosse mera exigência legal - no âmbito do licenciamento ambiental. Para tal, será analisada a participação nas audiências públicas do licenciamento ambiental da Linha 4 do metrô do Rio de Janeiro.

Palavras-chave: participação popular; acesso à informação; Estado Democrático-Participativo; licenciamento ambiental; audiência pública. 


\section{Sumário}

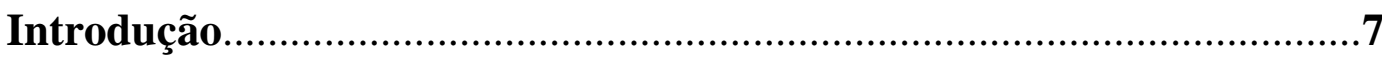

1. Estado Democrático Participativo e a proteção

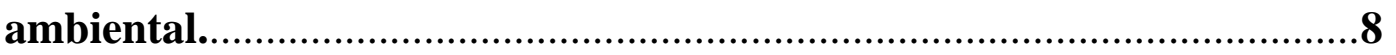

2. O direito à participação e à informação no Direito Ambiental Internacional. .18

3. Direito à participação e à informação no Direito Ambiental Brasileiro. .27

3.1. Aspectos gerais da participação e da informação no ordenamento jurídico ambiental brasileiro .27

3.1.1. A Política Nacional do Meio Ambiente..............................................27

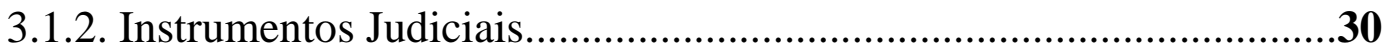

3.1.3. A Constituição Federal de 1988.........................................................33

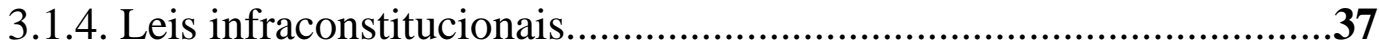

3.2 Participação pública e acesso à informação nos procedimentos de

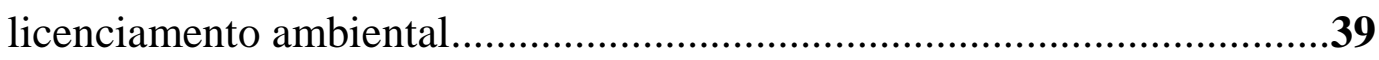

3.2.1. Audiências públicas nos licenciamentos ambientais..........................47

3.2.1.2. Audiências públicas em licenciamentos ambientais no Estado do Rio de Janeiro .59

4. A Linha 4 do metrô do Rio de Janeiro: breve análise da participação nas audiências públicas realizadas no licenciamento ambiental. .63

4.1. Breve histórico do licenciamento ambiental da Linha 4 do metrô do Rio de Janeiro 63

4.2. Análise crítica das audiências públicas.................................................69

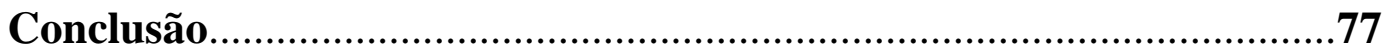

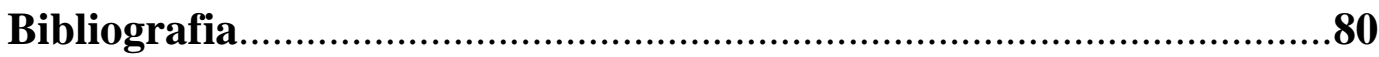




\section{Introdução}

Na atualidade, a participação popular ${ }^{1}$ e o acesso à informação em matéria ambiental significam a possibilidade que as pessoas têm de, individualmente ou reunidas em grupos, tomar parte nas instâncias de decisão relacionadas ao tema e, de exercer o controle sobre as omissões e atividades, tanto públicas quanto privadas, que sejam potencial ou efetivamente lesivas ao meio ambiente.

Através de consultas, comentários e audiências públicas, a participação popular pode propiciar integração e reforço na obrigação, estatal e coletiva, de proteger o meio ambiente.

É neste contexto que se insere o direito à participação e à informação no procedimento do licenciamento ambiental de atividades ou empreendimentos potencialmente causadores de significativa degradação ao meio ambiente.

Este trabalho busca expor a visão de que a efetiva participação da sociedade civil informada nos licenciamentos ambientais é ferramenta para defesa do meio ambiente e, em última instância, concretização do Estado Democrático-Participativo, consagrado na Constituição da República Federativa do Brasil de 1988 (CRFB/88).

Para tal, no primeiro capítulo será abordado o conceito de Estado Democrático-Participativo e sua relação com a proteção ambiental. No segundo capítulo, será analisado o direito à participação e à informação no Direito Ambiental Internacional, para, então, estudar tais direitos no ordenamento jurídico pátrio - o que é feito no terceiro capítulo.

Neste terceiro capítulo, analisam-se com maior profundidade as garantias de participação pública e acesso à informação no licenciamento

\footnotetext{
1 Nesta monografia, serão utilizadas, indistintamente, as expressões participação popular, participação pública, participação social, participação cidadã, participação do povo, participação da sociedade civil, participação comunitária em matéria ambiental, como referência à participação de indivíduos e entes representativos na proteção do meio ambiente. Sobre essas designações, ver FURRIELA, Rachel Biderman. Democracia, cidadania e proteção ao meio ambiente. São Paulo: Annablume: Fapesp, 2002. p. 27-36.
} 
ambiental, com enfoque na importância e finalidade das audiências públicas que ocorrem no bojo deste procedimento. Além disso, ainda neste capítulo, o presente trabalho faz um recorte para abordar a legislação sobre audiências públicas em licenciamentos ambientais no Estado do Rio de Janeiro.

Em seguida, no quarto e último capítulo, faz-se uma análise crítica da participação da sociedade civil nas audiências públicas no licenciamento ambiental da Linha 4 do metrô do Rio do Janeiro. 


\section{Estado Democrático Participativo e a proteção ambiental}

Este capítulo visa demonstrar a relevância da participação popular ${ }^{2}$ no contexto do Estado Democrático de Direito, como ferramenta de proteção do meio ambiente na sociedade contemporânea.

Em primeiro lugar se analisará os conceitos de democracia, Estado Democrático de Direito e de participação. Em segundo lugar, haverá uma sucinta menção sobre a evolução da participação da sociedade civil no âmbito político brasileiro, culminando na inserção de diversos mecanismos de participação popular no texto da Constituição da República Federativa do Brasil. Em terceiro lugar, serão abordados os tipos de participação social e sua importância para a consolidação do Estado DemocráticoParticipativo. Por fim, serão mencionadas as relações entre a participação e a proteção ambiental. ${ }^{3}$

A democracia é um conceito de origem grega, que, em linhas gerais, "revela um regime político em que o poder repousa na vontade do povo". 4 Na concepção de Abraham Lincoln: "a democracia é o governo do povo, pelo povo e para o povo". 5 Governo do povo significa que ele é o sujeito da democracia, ou seja, o povo é a o titular e a origem do poder. Nesta linha, está Constituição da República Federativa do Brasil (1988) ao dispor em seu artigo $1^{\circ}$, parágrafo único, que "todo o poder emana do povo", consagrando o princípio da soberania popular, que é, essencialmente, o

\footnotetext{
2 Nesta monografia, serão utilizadas, indistintamente, as expressões participação popular, participação pública, participação social, participação cidadã, participação do povo, participação da sociedade civil, participação comunitária em matéria ambiental, como referência à participação de indivíduos e entes representativos na proteção do meio ambiente. Sobre essas designações, ver FURRIELA, Rachel Biderman. Democracia, cidadania e proteção ao meio ambiente. São Paulo: Annablume: Fapesp, 2002. p. 27-36.

${ }^{3}$ Vale ressaltar que no capítulo 3 o presente trabalho irá aprofundar a pesquisa sobre a participação em matéria ambiental e sua previsão no Direito Ambiental brasileiro, afinal tem como objetivo último a análise da participação popular em audiências públicas no âmbito do licenciamento ambiental no Estado do Rio de Janeiro.

${ }^{4}$ SILVA, José Afonso da. Curso de Direito Constitucional Positivo. $31^{\mathrm{a}}$ ed. rev. atual. São Paulo: Editora Malheiros, 2008. p 125 e 126.

5 Abraham Lincoln (1809-1865), em seu discurso de 19/11/1863, em Gettysburg, afirmou que democracia é o governo do povo, pelo povo e para o povo (Democracy, government of the people, by the people, for the people, shall not perish from the Earth). Disponível em: <
} 
princípio de todo o regime democrático. Já a expressão governo pelo povo, revela como é o funcionamento da democracia, de forma que a livre manifestação de vontade, o consentimento e a adesão popular traduzem os fundamentos do governo. Por fim, governo para o povo expressa a finalidade da democracia, ou seja, o regime democrático é aquele que, sem autoritarismo, busca garantir o atendimento das necessidades da população com o máximo de segurança e bem-estar. ${ }^{6}$

Pode-se afirmar que a democracia não é um fim em si mesmo, mas um "instrumento de realização de valores essenciais de convivência humana", tais como, liberdade, igualdade e dignidade da pessoa, que compõem os direitos fundamentais do homem.

Desta forma, de acordo com José Afonso da Silva, "a democracia não é um mero conceito político abstrato e estático, mas é um processo de afirmação do povo e de garantias dos direitos fundamentais que o povo vai conquistando no decorrer da história". ${ }^{8}$

Cumpre destacar que a democracia é um conceito mais abrangente do que o de Estado Democrático de Direito que, por sua vez, não representa a união dos conceitos de Estado de Direito ${ }^{9}$ e Estado Democrático ${ }^{10}$,

http://www.planalto.gov.br/ccivil_03/revista/Rev 75/recensoes/AnaJamily.htm>. Acesso em: 23. mai. 2013.

${ }^{6}$ YODA, Ana Jamily Veneroso. A Democracia na Constituição Brasileira de 1988. Disponível em: < http://www.planalto.gov.br/ccivil_03/revista/Rev_75/recensoes/AnaJamily.htm> Acesso em: 25. mai. 2013.

${ }^{7}$ SILVA, José Afonso da. Curso de Direito Constitucional Positivo.p 125 e 126.

${ }^{8}$ SILVA, José Afonso da. Curso de Direito Constitucional Positivo. p 126.

${ }^{9}$ Em sua origem, o conceito de Estado de Direito é uma expressão da democracia liberal. Suas características eram: (a) submissão ao império da lei, que era o eixo central do seu conceito, sendo que a lei significava o ato emanado formalmente do Poder Legislativo, composto de representantes do povo - formado, entretanto, por somente aqueles considerados cidadãos; (b) divisão de poderes, separando com harmonia, imparcialidade e independência os poderes Legislativo, Executivo e Judiciário; (c) enunciado e garantia dos direitos individuais. Contudo, houve novas interpretações do conceito de Estado de Direito, gerando sua deformação. De acordo com Carl Schmitt a expressão Estado de Direito pode ter diversos significados, assim como a própria noção de Direito, e "designar tantas organizações quanto as que se aplica a palavra Estado". Na concepção clássica do Estado de , a igualdade se baseia nas leis, elemento formal, geral e abstrato. SILVA, José Afonso da. Curso de Direito Constitucional Positivo. p 112 e 113.

${ }^{10}$ O Estado Democrático de Direito visa à realização do princípio democrático como garantia geral dos direitos fundamentais da pessoa humana. Nas palavras de José Afonso da Silva, este "se funda no princípio da soberania popular, que impõe a participação efetiva e operante do povo na coisa pública, participação que não se exaure na simples formação das instituições representativas, que constituem um estágio da evolução do Estado Democrático, mas não o seu completo desenvolvimento". SILVA, José Afonso da. Curso de Direito Constitucional Positivo.. p 117. 
consistindo num conceito novo que supera os demais "na medida em que incorpora um componente revolucionário de transformação do status quo". ${ }^{11}$

Este foi o regime brasileiro consagrado na Constituição Federal, quando esta afirma que a República Federativa do Brasil se constitui em Estado Democrático de Direito. Isto significa que o Estado se funda no princípio democrático e no postulado da soberania popular (preâmbulo, art. $1^{\circ}$, caput e parágrafo único da Constituição Federal).

Assim, formalmente, a democracia concretiza-se no Estado Democrático de Direito brasileiro pela expressa previsão constitucional de uma sociedade livre, justa e solidária (art. $3^{\circ}, \mathrm{I}$ ), na qual o poder emana do povo, e deve ser exercido em nome dele, por vias diretas ou representativas (art. $1^{\circ}$, parágrafo único); participativa, onde a população participa nos na formação da decisão pública e dos atos de governo; ${ }^{12}$ pluralista, devido ao respeito à diversidade de ideias, culturas e etnias ${ }^{13}$, à tolerância para o diálogo entre opiniões e pensamentos divergentes, bem como, à coexistência de formas de organização e interesses diferentes da sociedade.

Quanto aos princípios do Estado Democrático de Direito, José Afonso da Silva indica: (a) princípio da constitucionalidade, que revela que o regime democrático brasileiro se funda na legitimidade de uma Constituição rígida, resultante da vontade popular e dotada de supremacia para vincular todos os poderes e os atos deles provenientes; (b) princípio democrático; que garante a vigência e eficácia dos direitos fundamentais, e segundo o qual o Brasil constitui uma democracia representativa pluralista e participativa, (c) sistema de direitos fundamentais, compreendendo os individuais e coletivos, ${ }^{14}$ sociais, ${ }^{15}$ culturais, ${ }^{16}$ ambiental ${ }^{17}$ e indigenista; ${ }^{18}$

\footnotetext{
${ }^{11}$ SILVA, José Afonso da. Curso de Direito Constitucional Positivo. $31^{\mathrm{a}}$ ed. rev. atual. São Paulo: Editora Malheiros, 2008. p 119.

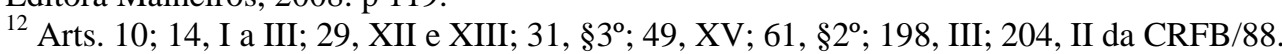

${ }^{13}$ Arts. $1^{\circ}, \mathrm{V} ; 17 ; 206$, III II da CRFB/88.

${ }^{14}$ Arts. $5^{\circ}, 8^{\circ}, 9^{\circ}, 10$ e 11 II da CRFB/88.

${ }^{15}$ Arts. $6^{\circ}, 7^{\circ}, 193-214,216-230$ II da CRFB/88.

${ }^{16}$ Arts. 215 a 217 II da CRFB/88.

${ }^{17}$ Art. 225 II da CRFB/88.
} 
(d) princípio da justiça social, expressamente disposto como o princípio da ordem econômica e social ${ }^{19}$; (e) princípio da igualdade ${ }^{20}$ (f) princípios $d a$ divisão de poderes ${ }^{21}$ e da independência do juiz; ${ }^{22}$ (g) princípio da legalidade; ${ }^{23} \mathrm{e}(\mathrm{h})$ princípio da segurança jurídica. ${ }^{2425} 26$

Por fim, nas palavras do referido autor, a "tarefa fundamental do Estado Democrático de Direito consiste em superar as desigualdades sociais e regionais e instaurar um regime democrático que realize a justiça social". 27

No que tange ao conceito de participação pública, nas palavras de Paulo Affonso Leme Machado, "participar significa que a opinião de uma pessoa pode ser levada em conta". ${ }^{28}$ Já Sherry R. Arnstein defende que somente se pode falar no termo participação pública quando há empoderamento popular, ou seja, a opinião da sociedade civil é, de fato, incorporada na decisão pública e/ou privada. ${ }^{29}$ No mesmo sentido, Diogo de Figueiredo Moreira Neto entende que é com a participação pública que se incrementa legitimidade no exercício do poder e, em relação à participação em face do Estado, afirma o autor se tratar de mecanismo de integração, reforço, alteração, inibição ou supressão da ação do poder estatal, motivo pelo qual, ela mesma representa autêntico exercício de poder. $^{30}$

\footnotetext{
${ }^{18}$ Arts. 213 e 232 II da CRFB/88.

${ }^{19}$ Arts. 170, caput e 193 II da CRFB/88.

${ }^{20}$ Art. $5^{\circ}$, caput, e I II da CRFB/88.

${ }^{21}$ Art. $2^{\circ}$ II da CRFB $/ 88$.

${ }^{22}$ Art. 95 II da CRFB/88.

${ }^{23}$ Art. $5^{\circ}$, II II da CRFB/88.

${ }^{24}$ Art. $5^{\circ}$, XXXVI a LXXIII II da CRFB/88.

${ }^{25}$ SILVA, José Afonso da. Curso de Direito Constitucional Positivo. p 122.

${ }^{26}$ José Gomes Canotilho desenvolveu os princípios do Estado de Direito Democrático no qual se funda a Constituição portuguesa, sendo estes aplicáveis ao Estado Democrático de Direito brasileiro. CANOTILHO, J. J. Gomes. Direito Constitucional. 6 ed. Coimbra: Editora Almedina. 1993. p. 373 e ss.

${ }^{27}$ SILVA, José Afonso da. Curso de Direito Constitucional Positivo. p 122.

${ }^{28}$ MACHADO, Paulo Affonso Leme. Direito Ambiental Brasileiro. $20^{a}$ ed rev., atual. e ampl. São Paulo: Malheiros Editores, 2012. p.129.

${ }^{29}$ ARNSTEIN, Sherry R. A Ladder of Citizen Participation. In: Journal of the American Planning Association, Vol. 35, Issue 4. Nova York: Kraus Reprinting Corporation, 1969. p. 216-224.

${ }^{30}$ MOREIRA NETO, Diogo de Figueiredo. Direito da participação política - legislativa, administrativa, judicial: fundamentos e técnicas constitucionais da democracia. Rio de Janeiro: Editora Renovar, 1992.p 24 e 57.
} 
Quanto à evolução da participação da sociedade civil na cena política nacional, Leonardo Avritzer revela que no final dos anos 1970 a sociedade civil se organizou autonomamente em relação ao Estado, em 1980 reivindicou parcerias nas políticas públicas, principalmente nas áreas de saúde, questões urbanas, assistência social e meio ambiente e, a partir da década de 1990, houve uma forte expansão de sua participação nessas áreas. 31 O mesmo autor afirma que, por via das emendas populares, foi proposta ampla legislação de interação entre a população e o Estado nas políticas públicas, apontando, desta forma, relação direta entre a forma de organização das políticas públicas no Brasil democrático e as ações da sociedade civil organizada durante a elaboração da Constituição Federal e da legislação infraconstitucional. ${ }^{32}$

Conforme exposto, a partir da década de 1980, com a redemocratização, maior espaço foi aberto para suprir a necessidade de interação da sociedade civil com o Poder Público. Em 1988, a Constituição Federal previu diversos instrumentos viabilizadores de que as demandas sociais chegassem à audiência do Poder Público com a potencialidade de

31 AVRITZER, Leonardo. Sociedade Civil e Participação Social no Brasil. Disponível em http://www.democraciaparticipativa.org/files/AvritzerSociedadeCivilParticipacaoBrasil.pdf. Acesso em: 11.04.13.

32 Como exemplo de dispositivos constitucionais que abrem espaço para a participação da sociedade civil, ao lado do Estado, em "instituições híbridas", Leonardo Avritzer ressalta os seguintes:

Artigo 29, incisos XII e XIII, sobre os Municípios, a Constituição Federal dispõe que "[o] Município reger-se-á por lei orgânica, (...) atendidos os princípios estabelecidos nesta Constituição, na Constituição do respectivo Estado e os seguintes preceitos: (...) cooperação das associações representativas no planejamento municipal [e] iniciativa popular de projetos de lei de interesse específico do Município, da cidade ou de bairros, através de manifestação de, pelo menos, cinco por cento do eleitorado; (...) cidadãos".

Artigo 194, parágrafo único, inciso IV, a respeito das políticas públicas de Seguridade Social, o texto constitucional assegura o "caráter democrático e descentralizado da administração, mediante gestão quadripartite, com participação dos trabalhadores, dos empregadores, dos aposentados e do Governo nos órgãos colegiados".

Artigo 204, inciso II, sobre Assistência Social, prevê a "participação da população, por meio de organizações representativas, na formulação das políticas e no controle das ações em todos os níveis".

No Artigo 227, parágrafo primeiro, sobre Família, a Criança, o Adolescente, o Jovem e o Idoso, dispõe a Constituição que "[o] Estado promoverá programas de assistência integral à saúde da criança, do adolescente e do jovem, admitida a participação de entidades não governamentais (...)". AVRITZER, Leonardo. Sociedade Civil e Participação Social no Brasil. Disponível em http://www.democraciaparticipativa.org/files/AvritzerSociedadeCivilParticipacaoBrasil.pdf.

Acesso em: 11.04.13. 
interferirem em suas decisões, consagrando o chamado Estado Democrático-Participativo.

Estado Democrático-Participativo é a denominação dada por Paulo Bonavides quando analisa o Estado constitucional contemporâneo, afirmando que:

Ao Estado liberal sucedeu o Estado social; ao Estado social há de suceder, porém, o Estado democrático-participativo que recolhe das duas formas antecedentes de ordenamento o lastro positivo da liberdade e da igualdade. E o faz numa escala de aperfeiçoamento qualitativo da democracia jamais dantes alcançada em termos de concretização (...). O Estado democrático-participativo tem, por conseguinte, sua fórmula mais acabada na expressão democracia participativa". ${ }^{33}$

Nessa linha, Álvaro Luiz Valery Mirra caracteriza o Estado

Democrático-Participativo como sendo aquele que

busca não só reafirmar os direitos sociais e a necessidade de garantia dos direitos e liberdades individuais, como também o que agrega, a ambas as categorias, os direitos de terceira geração, denominados direitos de solidariedade, como o direito ao meio ambiente ecologicamente equilibrado, e os direitos de quarta geração, como o direito à própria democracia (participativa), com expansão dos direitos políticos, para além dos direitos de votar e ser votado. ${ }^{34}$

No Estado Democrático-Participativo, existem três tipos de participação pública, qualificadas como direta, semidireta e indireta (ou representativa). ${ }^{35}$

Quanto à participação popular direta, o arcabouço legislativo brasileiro prevê que esta pode ser exercida pelos cidadãos individualmente considerados, isto é, aqueles estejam no exercício dos seus direitos políticos, por meio das seguintes hipóteses: plebiscito, $^{36}$ referendo, ${ }^{37}$ iniciativa popular ${ }^{38}$ e ação popular ${ }^{39}$. Além disso, o legislador brasileiro previu a possibilidade de participação direta através de uma coletividade de

\footnotetext{
${ }^{33}$ BONAVIDES, Paulo. Teoria constitucional da democracia participativa: por um direito constitucional de luta e resistência, por uma nova hermenêutica, por uma repolitização da legitimidade. São Paulo: Malheiros Ed., 2001. p.20.

${ }^{34}$ MIRRA, Álvaro Luiz Valery. Participação, processo civil e defesa do meio ambiente. $1^{\mathrm{a}}$ ed. São Paulo: Editora Letras Jurídicas, 2011. p;86.

${ }^{35}$ SILVA, José Afonso da. Direito Ambiental Constitucional. $7^{\mathrm{a}}$ ed., rev. e atual. São Paulo: Editora Malheiros, 2008. p. 136.

${ }^{36}$ Art. 14 , I da CRFB/88 e arts. $2^{\circ}$ a 10 da Lei $n^{\circ} 9.709 / 98$.

${ }^{37}$ Art. 14, II da CRFB/88 e arts $2^{\circ}, 10,11$ e 12 da Lei no 9.709/98.

${ }^{38}$ Art. 14 , III, e $61, \S 2^{\circ}$ da CRFB/88 e arts. 13 e 14 da Lei $n^{\circ}$ 9.709/98.

${ }^{39}$ Lei $^{\circ} 4.717 / 65$.
} 
indivíduos, independentemente da sua capacidade eleitoral e nacionalidade, como ocorre, por exemplo, nas consultas populares e audiências públicas.

Vale frisar que os projetos de lei de iniciativa popular, previstos na Constituição Federal e disciplinados na Lei n. 9.709/98, tem sua admissão vinculada à subscrição de, no mínimo, um por cento do eleitorado nacional, distribuído por pelo menos cinco Estados, com não menos de três décimos por cento dos eleitores de cada um deles. Da mesma maneira, está também condicionada a convocação de audiências públicas à solicitação de no mínimo cinqüenta cidadãos. ${ }^{40}$

Nota-se que, nestes casos de participação direta, o ordenamento jurídico brasileiro, ao impor o requisito da comprovação da representatividade dos cidadãos, foi de encontro ao caráter originário do poder a eles atribuído. ${ }^{41}$ Desta forma, tais exigências formais podem ser utilizadas para limitar a participação da sociedade civil, naquela acepção de empoderamento popular cunhada por Sherry R. Arnstein, ${ }^{42}$ no desenvolvimento de políticas públicas e no controle de decisões, ações e omissões públicas.

Ressalta-se ainda que a atuação direta da sociedade civil nas questões públicas não se limita às hipóteses previstas em lei, de forma que inúmeras e igualmente legítimas são as diversas formas de interação entre o cidadão e o Poder Público, como as passeatas, a desobediência civil e a greve $^{43}$.

Neste sentido, Diogo de Figueiredo Moreira Neto considera a participação direta dos indivíduos (em sentido amplo) como expressão originária do poder, em contraposição à participação coletiva e à atividade

\footnotetext{
${ }^{40}$ Art. $2^{\circ}$ da Resolução n. 09/87 do CONAMA.

41 MOREIRA NETO, Diogo de Figueiredo. Direito da participação política - legislativa, administrativa, judicial. p 57.

${ }^{42}$ ARNSTEIN, Sherry R. A Ladder of Citizen Participation. p. 216-224

${ }^{43}$ Lei $n^{\circ} 7.783 / 89$.
} 
política do Estado de orientação social, as quais são entendidas como expressões derivadas do poder. ${ }^{44}$

No que diz respeito à participação popular semidireta, esta é exercida pelos denominados entes intermediários, isto é, aqueles que estão entre os indivíduos e os representantes da população eleitos como tal. ${ }^{45}$

De acordo com o ordenamento jurídico pátrio, os entes intermediários legitimados a participar na defesa do meio ambiente são: (a) as associações civis sem fins lucrativos, as fundações privadas e as organizações não governamentais, (b) os sindicatos, (c) a Ordem dos Advogados do Brasil, e (d) o Ministério Público.

Por fim, a participação popular indireta se materializa na escolha episódica dos governantes, por meio do voto, característica essencial da democracia representativa. Nesse ponto, ressalta-se que a Constituição Federal, no parágrafo único de seu artigo $1^{\circ}$, consagra o princípio democrático, afirmando que "todo poder emana do povo, que o exerce por meio de representantes eleitos ou diretamente", e, mais adiante em seu artigo 14, prevê que "a soberania popular será exercida pelo sufrágio universal e pelo voto direto e secreto, com valor igual para todos". Contudo, a limitação da participação indireta se dá pelo fato de que, através do voto, os cidadãos apenas designam quem vai exercer o poder, sem, contudo, determinarem como este poder será exercido na defesa do bem ambiental. $^{46}$

De acordo com José Joaquim Gomes Canotilho, a concepção ampla de participação contempla a participação indireta, por meio do voto, em conformidade com os processos e as formas da democracia meramente representativa. Ao passo que, em um sentido mais estrito de participação, são levadas em consideração, sobretudo, a participação direta e semidireta,

\footnotetext{
${ }^{44}$ MOREIRA NETO, Diogo de Figueiredo. Direito da participação política - legislativa, administrativa, judicial. p 57.

${ }^{45}$ MIRRA, Álvaro Luiz Valery. Participação, processo civil e defesa do meio ambiente. p. 128.

${ }^{46}$ SILVA, José Afonso da. Curso de Direito Constitucional Positivo. P.137.
} 
nas quais se "verifica uma forma mais alargada de concurso dos indivíduos e cidadãos para a tomada de decisões". ${ }^{47}$

Ao que interessa mais diretamente a este trabalho, a relação entre a participação e a proteção ambiental foi consagrada no artigo 225 da Constituição Federal, ao expressamente incumbir à coletividade, ao lado do Poder Público, o dever de defender e de preservar o meio ambiente ecologicamente equilibrado para as presentes e futuras gerações - tema que será aprofundado no capítulo 3.

Portanto, num regime democrático participativo não há como afastar a sociedade civil das decisões públicas e privadas suscetíveis de afetar o equilíbrio do meio ambiente, patrimônio comum, necessário à sadia qualidade de vida desta e das próximas gerações. Assim, conclui-se que a participação popular e a proteção do meio ambiente são temas indissociáveis.

Insta, então, analisar com mais profundidade em que medida o Direito internacional e nacional contemplam e incentivam a participação cidadã (incluindo o acesso à informação idônea) na proteção e preservação do meio ambiente.

\footnotetext{
${ }^{47}$ CANOTILHO, J. J. Gomes. Direito Constitucional. p. 414.
} 


\section{O direito à participação e à informação no Direito Ambiental Internacional}

O presente capítulo pretende apresentar uma breve contextualização da participação popular e do acesso à informação no Direito Ambiental Internacional, analisando os principais documentos e eventos sobre o tema.

No final dos anos 1960 e início dos anos $1970,{ }^{48}$ a descoberta da emergência da questão ambiental contribuiu para que o público tomasse consciência da importância de se debater tais temas no cenário político, no intuito de pressionar e influenciar governos locais, nacionais e órgãos globais. Assim, foi reconhecida a pertinência da participação social nos debates, fóruns e eventos, tanto em âmbito interno dos países, quanto àqueles promovidos pela Organização das Nações Unidas (ONU).

Dentre outros motivos que dão causa à adesão social na defesa do meio ambiente, pode-se mencionar o princípio da solidariedade intergeracional, a titularidade difusa do bem ambiental, e o caráter multissetorial dos movimentos ambientalistas ${ }^{49}$.

\footnotetext{
${ }^{48}$ MIRRA, Álvaro Luiz Valery. Participação, processo civil e defesa do meio ambiente. p. $52 \mathrm{e}$ 53.

FURRIELA, Rachel Biderman. Democracia, cidadania e proteção ao meio ambiente. p. 27-36.

${ }^{49}$ De acordo com Álvaro Luiz Valery Mirra, "o movimento ambientalista tem sido analisado como um dos denominados "novos movimentos sociais" que emergiram nos anos 1960 e 1970, responsáveis pela inserção de novos temas na agenda política moderna, como no caso, a defesa do meio ambiente. Trata-se de um movimento transclassista que não tem um sujeito social bem definido, como se passa, por exemplo, com os movimentos feministas, negro e indígena, ultrapassando, diversamente, as fronteiras de classe, raça, cor, idade e sexo. O sistema de valores por ele defendido está fundado em preocupações de ordem pós-materialista, como o equilíbrio ecológico, a justiça social, a não violência e a solidariedade com as gerações futuras. Na sua evolução, o movimento ambientalista passou a ser visto, mais recentemente, como movimento histórico, por incorporar, ao mesmo tempo, um setor moderado, que atua dentro do sistema político, nos moldes de verdadeiro grupo de pressão, e um setor mais radical, o qual desafia o setor político e se posiciona de modo antagônico ao padrão vigente de sociedade, tal como os movimentos sociais típicos. Sob esse enfoque, considera-se que ambos os setores - moderado e radical - agem de forma sinérgica e, com isso, estimulam a redefinição do sistema político por intermédio da incorporação da proteção ambiental como elemento fundamental da democracia que se pretende seja instaurada nos países. Por essa razão, entende-se que o movimento ambientalista congrega, hoje, vários atores sociais (daí o caráter complexo e multissetorial) que orientam sua atuação no sentido da promoção da sustentabilidade ambiental, incluindo não só indivíduos, grupos e organizações não governamentais, ecologistas e ambientalistas propriamente ditos, como também cientistas, agentes de órgãos estatais, trabalhadores e sindicatos, indivíduos e organizações não governamentais de desenvolvimento social, religiosos, políticos, profissionais, educadores, artistas e empresários". MIRRA, Álvaro Luiz Valery. Participação, processo civil e defesa do meio ambiente. p.53
} 
O Direito Ambiental Internacional busca conciliar interesses de diversos países, por meio, dentre outros, da assinatura de tratados ou convenções, protocolos, declarações e agendas internacionais, que visam orientar o comportamento das nações na proteção do meio ambiente planetário, inclusive, em alguns casos, inspirando a produção de leis nacionais. A seguir serão analisados os principais documentos e eventos internacionais que abordam o tema do direito à participação e à informação na proteção do meio ambiente.

A Declaração Universal dos Direitos Humanos (1948), em relação ao direito à liberdade de opinião e expressão, afirma que "este direito inclui a liberdade de, sem interferências, ter opiniões e de procurar, receber e transmitir informações e ideias por quaisquer meios e independentemente de fronteiras" (art. 19).

O marco da emancipação do Direito Ambiental Internacional foi a Conferência de Estocolmo em 1972, que deu origem a Declaração de Estocolmo, cujos 26 princípios inspiraram e nortearam a construção de Convenções posteriores, tendo como pano de fundo o princípio da cooperação internacional (Princípio 20).

No que tange ao direito à informação ambiental, em seus Princípios 19 e 20, esta Declaração enfatiza a relevância da divulgação de informações, da educação, da pesquisa cientifica e do livre intercambio de experiências e de informações, visando garantir o acesso dos países em desenvolvimento às tecnologias ambientais.

Ressalta-se, ainda, que a referida Declaração consagrou o princípio da participação comunitária fundada na solidariedade intergeracional, sendo assim, uma das inspirações para a redação do artigo 225 da Constituição Federal de $1988 .{ }^{50}$

\footnotetext{
${ }^{50}$ MILARÉ, Édis. Direito do Ambiente: a gestão em foco: doutrina, jurisprudência, glossário. $7^{\mathrm{a}}$ ed rev., atual. e reform. São Paulo: Editora Revista dos Tribunais, 2011. p1512.
} 
Em 1982, foi divulgada pela Assembleia Geral da ONU a "Carta Mundial da Natureza", ${ }^{51}$ tida como uma verdadeira declaração dos direitos de todos os seres vivos. O seu Princípio 21 proclama que para a conservação da natureza é necessária a cooperação entre os Estados, bem como na medida do possível, entre as demais autoridades públicas, as organizações internacionais, os particulares, as associações civis e as empresas. Neste sentido, a referida Carta previu a participação ampla dos indivíduos e demais atores sociais na preservação do meio ambiente, por meio da cooperação e solidariedade.

Da mesma forma, o seu Princípio 23, estabeleceu a possibilidade de participação de toda pessoa, nos moldes da legislação do seu país, nos processos decisórios referentes ao meio ambiente que lhe concerne diretamente e, em caso de dano ou degradação, previu o acesso a recursos jurídicos para a devida reparação. Pode-se afirmar que esta Carta estabeleceu novos limites e padrões para a relação entre os homens e a Natureza, em nome da continuidade da vida.

A Conferência das Nações Unidas sobre Meio Ambiente e Desenvolvimento (ECO 92), ocorrida no Rio de Janeiro em 1992, reafirmou a Declaração da Conferência de Estocolmo, e avançou com os princípios da Declaração do Rio sobre Meio Ambiente e Desenvolvimento (Declaração do Rio).

Em seu Princípio 10, esta Declaração afirmou a importância da participação da sociedade na defesa ambiental. Vejamos:

A melhor maneira de tratar questões ambientais é assegurar a participação, no nível apropriado, de todos os cidadãos interessados. No nível nacional, cada indivíduo deve ter acesso adequado a informações relativas ao meio ambiente de que disponham as autoridades públicas, inclusive informações sobre materiais e atividades perigosas em suas comunidades, bem como a oportunidade de participar de processos de tomada de decisões. Os Estados devem facilitar e

\footnotetext{
${ }^{51}$ Resolução n. $37 / 7$ da ONU - World Charter for Nature. Disponível em < http://www.dhcii.uminho.pt/0_content/investigao/files_CRDTLA/convencoes_tratados_etc/carta_mundial_da_na tureza de 28 de outubro de 1982.pdf $>$. Acesso em: 26 mar. 2013.
} 
estimular a conscientização e a participação pública, colocando a informação à disposição de todos. ${ }^{52}$

Desta forma, a participação popular foi consagrada em âmbito internacional como ferramenta básica e imprescindível para proteção do meio ambiente, sendo reconhecidamente necessário que o Poder Público efetive a publicidade e garanta o acesso adequado à informação ambiental.

Neste passo, quanto ao direito à informação, os Princípios 10, 18 e 19 da referida Declaração prevêem obrigações recíprocas entre os Estados de notificarem-se em casos de desastres naturais ou demais emergências com efeitos transfronteiriços; mencionam a obrigatoriedade de informação sobre atividades potencial ou efetivamente causadoras de significativo impacto ambiental transfronteiriço; o direito à informação perante as autoridades públicas; e o dever dos Estados de disponibilizar informação para a sociedade.

Ainda na Rio 92, nasce do consenso entre os países representados naquele encontro mundial e o Fórum das Organizações NãoGovernamentais, a Agenda 21. Em seu Capítulo 40, este documento institui os programas de redução das diferenças em matéria de dados e de melhoria da disponibilidade da informação. Para que suas propostas e recomendações fossem implementadas com eficácia e velocidade pelos países, seu texto afirmou a necessidade de que cada autoridade local dialogasse com seus cidadãos, organizações locais e empresas privadas para aprovarem uma Agenda 21 local. Assim, a Agenda 21 Brasileira foi promulgada em 2002 e seu texto reconheceu como indispensável que a sociedade fosse mais participativa e que tomasse maior número de iniciativas próprias em prol da sustentabilidade.

Nesse sentido, assinalou a Comissão de Políticas de Desenvolvimento Sustentável e da Agenda 21 Nacional:

É preciso ressaltar, uma vez mais, que a Agenda 21 Brasileira não é um plano de governo, mas um compromisso da sociedade em termos de escolha de cenários de

52 Relatório da Conferência da Organização das Nações Unidas sobre Meio Ambiente e Desenvolvimento, A/CONF.151/26 (Vol. I). Disponível em < http://www.un.org/documents/ga/conf151/aconf15126-1annex1.htm. >. Acesso em 24 mar. 2013. 
futuros. Praticar a Agenda 21 pressupõe a tomada de consciência individual dos cidadãos sobre o papel ambiental, econômico, social e político que desempenham em sua comunidade. Exige, portanto, a integração de toda a sociedade na construção desse futuro que desejamos ver realizado. Uma nova parceria, que induz a sociedade a compartilhar responsabilidades e decisões junto com os governos, permite maior sinergia em torno de um projeto nacional de desenvolvimento sustentável. ${ }^{53}$

Em 2002 foi realizada pela ONU a Cúpula Mundial sobre Desenvolvimento Sustentável em Joanesburgo, na África do Sul, conhecida como Rio+10, visto que seu objetivo era discutir os avanços alcançados pela Agenda 21 e outros acordos da Cúpula de 1992. No que diz respeito à participação pública, esta Conferência reforçou o Princípio 10 da Declaração do Rio, além de ter sido marcada pela participação da sociedade civil e de organizações não governamentais (ONGs) nos fóruns do evento. ${ }^{54}$. Neste passo, a Declaração de Joanesburgo frisa a importância do multilateralismo democrático e da participação do público nas questões ambientais, além de relembrar os compromissos firmados entre os países, elencar os desafios planetários comuns às diversas nações ali representadas, reafirmar o compromisso mundial com o desenvolvimento sustentável e assumir o compromisso dos países de agirem em conjunto para a concretização do objetivo de garantir às futuras gerações um mundo melhor.

Especificamente sobre o acesso à informação como ferramenta de proteção ambiental, em 1998, na Dinamarca, foi adotada a Convenção da Comissão Econômica das Nações Unidas para a Europa (UNECE, na sigla

\footnotetext{
53 Disponível em < http://www.mma.gov.br/estruturas/agenda21/_arquivos/acoes2edicao.pdf $>$. Acesso em 24 mar. 2013.

${ }^{54}$ Havia cerca de 22 mil participantes na Cúpula Mundial sobre Desenvolvimento Sustentável em Joanesburgo. Cerca de 10.000 delegados foram credenciados pela ONU em Johannesburgo para participar da Cúpula - incluindo participantes dos Estados-Membros, organizações intergovernamentais, observadores oficiais, agências especializadas e organizações afins, e os membros associados das comissões regionais. Além disso, cerca de 8.000 representantes de organizações dos grupos principais, que são: mulheres, crianças e jovens, indígenas, organizações não governamentais, autoridades locais, trabalhadores e sindicatos, comércio e indústria, comunidades e agricultores científica e tecnológica. Ainda, 4.000 pessoas da mídia foram credenciados para a Cúpula. Um grande número de pessoas participaram de eventos paralelos relacionados com a Cúpula, como o Fórum Global da Sociedade Civil, mas como a a ONU não organizou estes eventos não há números registrados para eles. Estes valores não incluem o pessoal da ONU, pessoal de apoio local e pessoal de segurança. Disponível em: <
} 
em inglês) sobre Acesso à Informação, Participação do Público no Processo

de Tomada de Decisão e Acesso à Justiça em Matéria de Ambiente, designada como Convenção de Aarhus. ${ }^{55}$ Destaca-se o disposto no artigo $2^{\circ}$, item 3 deste documento:

A expressão 'informações sobre o meio ambiente' designa toda informação disponível sob forma escrita, visual, oral ou eletrônica ou sob qualquer outra forma material, sobre: a) o estado do meio ambiente, tais como o ar e a atmosfera, as águas, o solo, as terras, a paisagem e os sítios naturais, a diversidade biológica e seus componentes, compreendidos os OGMS, e a interação desses elementos; b) fatores tais como as substancias, a energia, o ruído e as radiações e atividades ou medidas, compreendidas as medidas administrativas, acordos relativos ao meio ambiente, políticas, leis, planos e programas que tenham, ou possam ter, incidência sobre os elementos do meio ambiente concernente à alínea "a", supramencionada, e a análise custo/beneficio e outras análises e hipóteses econômicas utilizadas no processo decisório em matéria de meio ambiente; c) o estado de saúde do homem, sua segurança e suas condições de vida, assim como o estado dos sítios culturais e das construções na medida onde são, ou possam ser, alterados pelo estado dos elementos do meio ambiente ou, através desses elementos, pelos fatores, atividades e medidas visadas na alínea "b", supramencionada. ${ }^{56}$

Em vigor desde 2001, esta Convenção reconheceu que a mais ampla participação do público nos processos de tomada de decisões e que a melhoria do seu acesso à informação são "ferramentas essenciais para garantir a sensibilização da população para as questões ambientais e promover uma melhor aplicação do direito do ambiente". 57

A Convenção de Aarhus contribuiu com o aumento da responsabilidade e da transparência no processo de tomada de decisões, sobretudo nos setores do governo, exigindo que estes passem a dar

http://www.johannesburgsummit.org/html/basic_info/faqs.html\#joburg1>. Acesso em: 05.mai.2013.

${ }^{55}$ A Convenção foi adotada em Aarhus (Dinamarca) em 25 de junho de 1998, por ocasião da $4^{\text {a }}$ Conferência Ministerial “Ambiente para a Europa", tendo entrado em vigor em 30 de outubro de 2001, e celebrada pela então Comunidade Europeia (hoje, União Europeia) em 17 de fevereiro de 2005, por meio da decisão 2005/370/CE. O Secretariado da Convenção funciona junto à ONU, em Genebra (Suíça). Para o texto da Convenção, v. United Nations Treaty Series, vol. 2161, p. 447, bem como em: <http://www.unece.org/env/pp/documents/cep43e.pdf >. Para o status das ratificações, consultar: <http://www.unece.org/env/pp/ratification.htm>. Acesso em 24 mar. 2013.

${ }^{56}$ Disponível em: <http://www.unece.org/env/pp/documents/cep43e.pdf>. Acesso em 24 mar. 2013.

Disponível em e http://www.unece.org/fileadmin/DAM/env/pp/EU\%20texts/conventioninportogese.pdf >. Acesso em 24 mar. 2013. 
conhecimento ao público dos procedimentos adotados ou a adotar, quando relativos às questões ambientais. ${ }^{58}$

Outrossim, a referida Convenção estabeleceu as regras básicas para a promoção do envolvimento dos cidadãos nas questões ambientais e a execução da legislação ambiental, fundamentando-se em três pilares, quais sejam, o acesso à informações sobre o ambiente, a participação do público nos processos de tomada de decisões e o acesso à justiça. ${ }^{59}$

Apesar do Brasil ainda não ter ratificado a Convenção, ${ }^{60}$ na opinião de Patryck de Araújo Ayala e Valerio de Oliveira Mazzuoli:

Ela opera como paradigma e referencial ético no que toca à cooperação internacional para a proteção do meio ambiente, na medida em que consagra aos cidadãos o acesso à informação, à participação na tomada de decisões e o ingresso à justiça em matéria ambiental. ${ }^{61}$

Em 1990, da reunião mundial de associações de direito ambiental, surgiu a primeira Declaração de $\operatorname{Limoges}^{62}$ que reconheceu o direito à informação como fase indispensável ao procedimento de autorização ambiental. No mesmo sentido, a segunda Declaração (2001) estabeleceu, em seu item 2.2, que:

A participação pública nas matérias ambientais, incluindo acesso à informação, ao procedimento de participação na tomada de decisões e o acesso à justiça, serve para proteger os direitos humanos a um meio ambiente decente; contribui para a qualidade e a legitimidade das decisões oficiais e efetividade nas políticas de sustentabilidade e constitui um importante elemento da democracia. ${ }^{63}$

\footnotetext{
58 MACHADO, Paulo Affonso Leme. Direito à informação e meio ambiente. São Paulo: Malheiros Editores, 2006. p 124.

${ }^{59}$ MACHADO, Paulo Affonso Leme. Direito à informação e meio ambiente. p125.

${ }^{60}$ A Convenção de Aarhus enquadra-se na categoria dos tratados de direitos humanos lato sensu, por versar sobre a proteção ambiental. Desta forma, caso ocorra sua incorporação ao Direito brasileiro, ela terá status hierárquico de "norma constitucional". Contudo, não é neste trabalho o lugar de se analisar o tema da hierarquia dos tratados sobre meio ambiente na ordem jurídica brasileira.

${ }^{61}$ MAZZUOLI, Valerio de Oliveira; AYALA, Patryck de Araújo. Cooperação internacional para a preservação do meio ambiente: o direito brasileiro e a Convenção de Aarhus. Rev. direito GV, São Paulo , v. 8, n. 1, Junho, 2012 . Disponível em $<$ http://www.scielo.br/scielo.php?script=sci_arttext\&pid=S180824322012000100012\&lng=en\&nrm=iso>. Acesso em 24 mar. 2013.

${ }^{62}$ Disponível em:< http://www.cidce.org/.> Acesso em 6 abr. 2013.

${ }^{63}$ Disponível em: $<$ http://www.cidce.org/>. Acesso em 6 abr. 2013.
} 
Em 2005, o Colóquio de Limoges acerca do direito e das políticas públicas de meio ambiente e desenvolvimento sustentável, especialmente nas relações Brasil-França, frisou:

Que uma proteção adequada do meio ambiente é essencial ao bem-estar do homem, assim como ao gozo de seus direitos fundamentais; compreendem-se aqui o próprio direito à vida, como o direito à informação em matéria ambiental, Que cada um tem o direito de viver em um ambiente capaz de assegurar sua saúde e seu bem-estar, e o direito, a ser exercido individualmente ou em associação, de proteger e de melhorar o meio ambiente, velando, assim, pelo interesse das gerações presentes e futuras,

O papel importante que os cidadãos, as organizações não-governamentais, as autoridades públicas e o setor privado podem ter no que concerne a proteção do meio ambiente (...). ${ }^{64}$

Tais documentos revelam a irrefutável conexão entre a tutela ambiental o direito de ser informado. Acerca deste tema, Paulo Affonso Leme Machado afirma que o acesso à informação é imprescindível para o processo de educação da sociedade como um todo, salientando que a

Informação ambiental deve ser prevista nas convenções internacionais de forma a atingir não somente as pessoas do País onde se produza o dano ao ambiente, como também atingir as pessoas de Países vizinhos que possam sofrer as consequências do dano ambiental.

O monitoramento das informações ambientais deve ser levado a efeito não só pode Poder Público, mas também pelas organizações não governamentais, que, para esse fim, merecem receber auxilio cientifico e financeiro. Os métodos e recursos da Informática devem ser utilizados para a informação e monitoramento ambientais, insistindo-se na cooperação internacional, de forma que os Países subdesenvolvidos e em desenvolvimento possam implementar esses procedimentos.

A não informação de eventos significativamente danosos ao meio ambiente por parte dos Estados merece ser considerada crime internacional. ${ }^{65}$

No mesmo sentido, os juristas da Comissão Mundial sobre Meio

Ambiente e Desenvolvimento afirmaram que os dados ambientais devem estar disponíveis para consulta pública e, por isso, devem ser publicados. ${ }^{66}$ Desta forma, é por meio da publicação que se garante o acesso à informação.

\footnotetext{
${ }^{64}$ Disponível em: $<$ http://www.cidce.org/pdf/Declaracao\%20de\%20Limoges.pdf. $>$ Acesso em 6 abr. 2013.

${ }^{65}$ MACHADO, Paulo Affonso Leme. Direito Ambiental Brasileiro. p 128.

${ }^{66}$ MACHADO, Paulo Affonso Leme. Direito Ambiental Brasileiro. p 126.
} 
Diante do exposto, ressalta-se a lição de Guilherme José Purvin de Figueiredo ao afirmar que:

$\mathrm{O}$ crescente número de convenções internacionais sobre meio ambiente indica claramente que nossos governantes já se deram conta do risco da própria espécie humana do planeta, em decorrência do aquecimento global, da poluição da água, do solo e do ar, da radioatividade e da extinção de espécies da fauna e da flora. No entanto, há de se convir que a existência de tratados cuidando de temas correlatos, aliada à inexistência de uma coordenação internacional destinada à implementação de políticas planetárias não contribuem para uma solução eficiente e rápida dos problemas ambientais que nos afligem. ${ }^{67}$

Conforme exposto, os principais documentos adotados ou oriundos das mais expoentes conferências internacionais, assim como as comissões e reuniões destinadas a tratar da defesa do meio ambiente, sempre enfatizaram, ou ao menos, mencionaram a imperiosidade da participação do maior número possível de atores da sociedade e do acesso à informação como elementos preponderantes para a preservação ambiental, local, regional e/ou global.

Conclui-se que, no plano internacional, a participação pública e o acesso à informação são plenamente reconhecidos como necessários e imprescindíveis à proteção do meio ambiente, devendo o Direito Ambiental nacional encontrar mecanismos formais de garantir tais direitos.

A seguir, analisar-se-á a incorporação da participação pública e do direito à informação no ordenamento jurídico do Brasil.

\footnotetext{
${ }^{67}$ FIGUEIREDO, Guilherme José Purvin de. Curso de Direito Ambiental. $5^{\text {a }}$ ed rev., atual. e
} reform. São Paulo: Editora Revista dos Tribunais, 2012. p106. 


\section{Direito à participação e à informação no Direito Ambiental Brasileiro}

Este capítulo fará uma concisa análise do direito à participação e à informação no arcabouço jurídico ambiental brasileiro. Para tal, serão analisadas as normas mais relevantes sobre o tema.

Em seguida, o enfoque será a previsão de tais direitos na legislação sobre licenciamento ambiental, tanto em âmbito federal, quanto na esfera do Estado do Rio de Janeiro.

\subsection{Aspectos gerais da participação e da informação no ordenamento jurídico ambiental brasileiro}

Neste trabalho propõe-se expor alguns aspectos da legislação pátria considerados mais relevantes no que diz respeito à previsão de participação e acesso à informação em matéria ambiental. As normas concernentes ao licenciamento ambiental, devido à sua relevância para o presente trabalho, serão abordadas adiante.

Assim, serão analisadas a Lei da Política Nacional do Meio Ambiente, a Constituição Federal, os instrumentos judiciais e as leis infraconstitucionais, com o objetivo de expor os aspectos considerados mais importantes para o tema deste trabalho relacionados à fundamentação legal da participação popular e do acesso à informação na defesa do meio ambiente nacional.

\subsubsection{A Política Nacional do Meio Ambiente}

A Lei da Política Nacional do Meio Ambiente - PNMA (Lei n. 6.938/81) é uma importante baliza da participação da sociedade na política ambiental brasileira, pois com ela previu-se a integração entre representantes do movimento ambientalista e outros representantes da 
sociedade civil na composição do Conselho Nacional do Meio Ambiente $(\text { CONAMA })^{68}$ - órgão colegiado fruto da mesma lei.

Conforme o entendimento de Diogo de Figueiredo Moreira Neto, os órgãos colegiados são espaços participativos privilegiados, pois a participação insere-se na própria estrutura da Administração Pública, possuindo caráter permanente ao contrário das demais formas de participação, nas quais a intervenção popular ocorre de maneira esporádica e transitória. ${ }^{69}$

Desta forma, os órgãos colegiados caracterizam-se por sua potencialidade de participação popular direta, funcionando "como canais institucionais regulares e permanentes para que a voz ou a vontade do administrado tenha acesso imediato à Administração". ${ }^{70}$

Entretanto, há indicativos de deficiência da atuação dos entes intermediários nestes órgãos, ${ }^{71}$ sendo apontado como um dos motivos dessa debilidade a falta de composição paritária dos órgãos colegiados, o que afeta a real possibilidade de influência da sociedade civil na formulação das políticas públicas, gerando, muitas vezes, a rejeição das propostas ambientalistas. $^{72}$

Especificamente em relação ao CONAMA, órgão ambiental colegiado participativo com atribuições administrativas, vale ressaltar que é composto por representantes de entes e organizações da sociedade civil, como as associações ambientalistas, junto a órgãos e agências governamentais e de entidades empresariais, todos com direito a voto, e do Ministério Público, este, contudo, sem direito a voto. Nota-se que, de

\footnotetext{
${ }^{68}$ Criado pela Lei n. 6.938/81, o CONAMA é um órgão colegiado de âmbito nacional, integrante da estrutura do Poder Executivo Federal, com atribuições consultivas e deliberativas do Sistema Nacional de Meio Ambiente (SISNAMA). Dentre suas competências está a de estabelecer normas, critérios e padrões relativos ao controle e à manutenção da qualidade do meio ambiente com vistas ao uso racional dos recursos ambientais (art. $8^{\circ}$, VII).O CONAMA é composto por um colegiado representativo de cinco setores (União, Estados, Municípios, iniciativa privada e sociedade civil).

${ }^{69}$ MOREIRA NETO, Diogo de Figueiredo. Direito da participação política - legislativa, administrativa, judicial. p 129.

${ }^{70}$ MOREIRA NETO, Diogo de Figueiredo. Direito da participação política - legislativa, administrativa, judicial. p 130.

${ }^{71}$ FURRIELA, Rachel Biderman. Democracia, cidadania e proteção ao meio ambiente. 100.

${ }^{72}$ FURRIELA, Rachel Biderman. Democracia, cidadania e proteção ao meio ambiente. p 71-82.
} 
acordo com a legislação vigente, mais de dois terços dos membros do CONAMA com direito a voto representam órgãos e agências governamentais. ${ }^{73}$

Por tudo isso, há que se levar em consideração a possibilidade de não se concretizar efetiva influência dos representantes da população dedicados à causa ambiental nas decisões colegiadas deste órgão.

Ainda assim, constitui o CONAMA relevante canal participativo na formulação de normas de proteção do meio ambiente, influenciando, por meio de suas resoluções, a formação e a evolução de normas de proteção ambiental, como por exemplo, as resoluções do CONAMA sobre o licenciamento ambiental, ${ }^{74}$ o estudo de impacto ambiental ${ }^{75}$ e as audiências públicas. $^{76}$

Neste passo, vale frisar que a PNMA previu, dentre outros, dois instrumentos administrativos ambientais autônomos porém conectados: a avaliação de impactos ambientais (art. $9^{\circ}$, III) e o licenciamento ambiental (art. $\left.9^{\circ}, \mathrm{IV}\right)$. Ambos os instrumentos, cada qual da sua maneira, garante o direito à participação e à informação em matéria ambiental, conforme se analisará adiante.

No que diz respeito ao acesso à informação na defesa do meio ambiente, este foi inscrito como um dos objetivos da PNMA, se destacando em um de seus importantes instrumentos, qual seja, o Sistema Nacional de Informações sobre Meio Ambiente - SINIMA. ${ }^{77}$

Ademais, a referida política prescreve como um de seus princípios a educação ambiental, em todos os níveis de ensino, inclusive a educação da comunidade, objetivando capacitar a população para participação ativa e informada na defesa do meio ambiente. ${ }^{78}$

\footnotetext{
${ }^{73}$ Art. $5^{\circ}$, inciso I a VII, do Decreto n. 99.274/90.

${ }^{74}$ Resolução CONAMA n. 237/97.

${ }^{75}$ Resolução CONAMA n 01/86

${ }^{76}$ Resolução CONAMA n 09/87.

${ }^{77}$ Instituído pelo artigo $9^{\circ}$, VII, da Lei 6.938/81 e regulamentado pelo artigo 11, II, do Decreto 99.274/90, o SISNIMA objetiva viabilizar a sistematização, o tratamento, o armazenamento e a divulgação de informações, documentos e dados ambientais.

${ }^{78}$ Art. $2^{\circ}, \mathrm{X}$, da Lei 6.938/81.
} 
Assim, pode-se afirmar que a PNMA é um marco legislativo na previsão de importantes instrumentos e institutos que para lograrem êxito na sua finalidade de tutela ambiental estão permeados de participação pública, transparência e acesso à informação.

\subsubsection{Instrumentos Judiciais}

A participação judicial em matéria ambiental é relevante, pois traz uma possibilidade maior de efetividade quando comparada com a participação legislativa e administrativa, que na maioria das vezes têm natureza meramente propositiva e consultiva. São menos freqüentes as hipóteses de vinculação dos órgãos legislativos e administrativos às manifestações da sociedade civil. ${ }^{79} 80$

Conforme leciona Álvaro Luiz Valery Mirra, a finalidade da participação popular judicial é:

(...) incrementar a implementação do Direito Ambiental, propiciar o controle pela sociedade da legalidade e da legitimidade das ações e omissões públicas e privadas relacionadas com o meio ambiente, garantir o acesso participativo à justiça para a defesa do meio ambiente e assegurar a própria participação pública ambiental. $^{81}$

Os instrumentos judiciais mais utilizados pela sociedade civil em defesa do meio ambiente e, por isso merecem destaque, são a ação civil pública e a ação popular.

A Lei n. 7.347/85, conhecida como a Lei da Ação Civil Pública, incluiu as associações no rol dos legitimados ativos para a sua propositura, conforme dispõe o artigo $5^{\mathrm{o} 82}$ :

\footnotetext{
${ }^{79}$ MIRRA, Álvaro Luiz Valery. Participação, processo civil e defesa do meio ambiente. p.168.

${ }^{80}$ Nos casos em que há atribuição de natureza deliberativa para a participação popular, como plebiscitos, referendos legislativos e administrativos e, ainda, atuação de representantes de entes intermediários em órgãos colegiados com competências normativas e executivas, tal como o CONAMA -, deve-se levar em consideração que nem sempre ela obtém os resultados esperados. Isso por que os plebiscitos e os referendos não têm sido utilizados para a tomada de decisões ou consultas públicas em matéria ambiental. Além disso, já foi mencionada a deficiência de representatividade da sociedade civil na composição do CONAMA. Daí a importância da participação judicial na tutela do meio ambiente como via direta para influenciar os rumos do desenvolvimento sustentável do país.

${ }^{81}$ MIRRA, Álvaro Luiz Valery. Participação, processo civil e defesa do meio ambiente. p.169.

${ }^{82}$ Redação dada pela Lei n. 11.448/07.
} 
I - o Ministério Público;

II - a Defensoria Pública;

III- a União, os Estados, o Distrito Federal e os Municípios;

IV- a autarquia, empresa pública, fundação ou sociedade de economia mista;

$\mathrm{V}$ - a associação que, concomitantemente:

a) esteja constituída há pelo menos 1 (um) ano nos termos da lei civil;

b) inclua, entre suas finalidades institucionais, a proteção ao meio ambiente, ao consumidor, à ordem econômica, à livre concorrência ou ao patrimônio artístico, estético, histórico, turístico e paisagístico.

(grifo nosso)

Importa apontar que a referida lei está em consonância com o já mencionado Princípio 10 da Declaração do Rio que afirma que "deve ser proporcionado acesso aos procedimentos judiciais e administrativos, incluindo compensação e reparação". Desta forma, a expressa inclusão das associações ambientalistas dentre os legitimados abriu as portas do Poder Judiciário à participação popular, sendo, portanto, um enorme ganho social.

Por esse motivo, pode-se afirmar que a Lei da Ação Civil Pública foi importante na garantia do direito de acesso à justiça ao possibilitar que tais associações proponham ações judiciais de tutela ambiental, tanto preventiva quanto reparatória. ${ }^{83}$

O texto constitucional dispõe ser "função institucional do Ministério Público" a promoção desta ação judicial na defesa do meio ambiente. ${ }^{84}$ Sobre o tema, Vladimir Passos de Freitas afirma que:

A competência do Ministério Público para iniciar a ação civil em juízo é criação brasileira. Na maioria dos países ela não é admitida. A solução brasileira passa certamente por dois fatores. O primeiro é a estrutura administrativa existente e as garantias dadas pela Constituição Federal e o Ministério Público. O segundo é o ainda recente processo de democratização que afeta o País, fazendo com que somente agora, e aos poucos, se exercitem os direitos de cidadania. ${ }^{85}$

\footnotetext{
${ }^{83}$ De fato, foi uma evolução legislativa em relação à PNMA, no sentido de criação de mecanismos que viabilizem a efetivação do Estado Democrático-Participativo. A respeito dos legitimados à propositura de ação de responsabilidade civil por danos causados ao meio ambiente, a PNMA incluiu o Ministério Público da União e dos Estados (art. 14, $\S 1^{\circ}$ ), mas não logrou êxito na aprovação das associações, que foram vetadas pelo então Chefe do Executivo. MACHADO, Paulo Affonso Leme. Direito Ambiental Brasileiro. p.436.

${ }^{84}$ Art. 129, inciso III, da CRFB/88. Além disso, o texto constitucional, em seu artigo 127, define o Ministério Público como "a Instituição permanente, essencial à função jurisdicional do Estado, incumbindo-lhe a defesa da ordem jurídica, do regime democrático e dos interesses sociais e individuais indisponíveis".

${ }^{85}$ FREITAS, Vladimir Passos de. A Constituição Federal e a Efetividade das Normas Ambientais. $2^{\mathrm{a}}$ ed., São Paulo, Editora Revista dos Tribunais, 2002. p.38.
} 
Ainda com relação aos instrumentos judiciais, cabe mencionar a ação popular como ferramenta de participação social na tutela do meio ambiente. Instituída no ordenamento jurídico brasileiro pela Lei n. 4.717/65, esta ação pode ser ajuizada por qualquer cidadão no gozo de seus direitos políticos (art. $1^{\circ}, \S 3^{\circ}$ ) e sua finalidade é a declaração de nulidade ou anulação dos atos lesivos ao patrimônio público, nele incluído, o ambiente.

Esta lei, originalmente, sujeitava o perdedor da ação ao pagamento de "custas e preparo final", o que desestimulava o uso desta ferramenta. ${ }^{86}$ Neste aspecto, a Constituição Federal trouxe uma nova perspectiva para a utilização do instrumento, ao garantir em seu artigo $5^{\circ}$, inciso LXXIII, que:

Qualquer cidadão é parte legítima para propor ação popular que vise a anular ato lesivo ao patrimônio público ou de entidade de que o Estado participe, à moralidade administrativa, ao meio ambiente e ao patrimônio histórico e cultural, ficando o autor, salvo comprovada má-fé, isento de custas judiciais e do ônus da sucumbência.

(grifo nosso)

De acordo com José Rubens Morato Leite, "a diferença primordial da tutela jurisdicional subjetiva, via ação popular, das demais de índole individualista está no fato de que esta última funda-se num interesse próprio" e, em relação à ação popular na defesa do bem ambiental, afirma que "o ressarcimento não se faz em prol do indivíduo, mas sim indiretamente em favor da coletividade, por se tratar de um bem indivisível e de conotação social". ${ }^{87}$

Neste sentido, afirma Diogo de Figueiredo Moreira Neto:

(...) como a sedimentação dos interesses coletivos é um processo permanente, pois resulta da própria societização dos grupos de qualquer natureza, explica-se por que se vem estendendo e ampliando às entidades sociais não estatais, em ritmo, intensidade e importância crescentes, o acesso a novos e criativos institutos processuais, através dos quais se logra não só a satisfação dos respectivos interesses coletivos como a ampliação do controle de legitimidade da ação do Estado e de seus delegados.

O mesmo ocorre com relação aos interesses difusos. Expandindo-se o número de intitulados à provocação do Poder Judiciário para defendê-los, como ocorre caracteristicamente nos institutos da ação popular e da ação civil pública, assegura-se também vigilância e controles mais amplos sobre a legitimidade da

\footnotetext{
${ }^{86}$ MACHADO, Paulo Affonso Leme. Direito Ambiental Brasileiro. p.428.

${ }^{87}$ LEITE, José Rubens Morato. Ação popular - Um exercício da cidadania ambiental? Revista de Direito Ambiental 17/128, São Paulo. Editora Revista dos Tribunais, janeiro-março/2000.
} 
ação do Estado e de outras entidades estatais ou não, no tocante a valores sociais extremamente sensíveis.

Como se pode concluir, a participação judicial se mostra politicamente relevante não tanto no caso de dedução de interesses individuais, mas de salvaguarda de interesses metaindividuais, cuja afirmação ou sacrifício podem repercutir ponderavelmente sobre a sociedade. ${ }^{88}$

Desta forma, com um sistema processual adequado e compatível com o Estado Democrático-Participativo, a participação judicial revela-se como instrumento capaz de realmente aproximar a população do controle efetivo sobre as ações e omissões públicas e privadas suscetíveis de causar degradação ao direito humano fundamental ao meio ambiente ecologicamente equilibrado.

\subsubsection{A Constituição Federal de 1988}

A Constituição da República Federativa do Brasil de 1988 inovou ao tratar do meio ambiente e a mencionar a expressão meio ambiente, elevando a defesa deste bem à condição de princípio constitucional e consagrando-o como direito fundamental de todos. Por isso, pode-se considerá-la como um dos mais significativos momentos, senão o maior, do Direito Ambiental Brasileiro, como ressalta Tiago Fensterseifer:

A proteção do ambiente no cenário jurídico brasileiro tem dois momentos históricos bem delimitados. O 'divisor de águas' e marco normativo a traçar temporalmente os dois momentos é a promulgação da Lei Fundamental brasileira em 1988. Portanto, pode-se dizer que hoje nós nos encontramos diante de uma nova 'era' da proteção ambiental no contexto jurídico brasileiro, tendo a Constituição de 1988 incorporado ao seu corpo normativo um capítulo próprio para a tutela do meio ambiente e, portanto, 'constitucionalizado' a proteção ambiental. $^{89}$

(grifo nosso)

Diversos capítulos do texto constitucional contêm disposições sobre meio ambiente. Entretanto, no seu Título VIII ("Da Ordem Social”), no Capítulo VI, a Constituição Federal coloca em relevo tal tutela, ao consagrar que "todos têm direito ao meio ambiente ecologicamente

${ }^{88}$ MOREIRA NETO, Diogo de Figueiredo. Direito da participação política - legislativa, administrativa, judicial p.144.

${ }^{89}$ FENSTERSEIFER, Tiago. Direitos Fundamentais e Proteção do Ambiente. Porto Alegre: Livraria do Advogado, 2008. p 159. 
equilibrado, bem de uso comum do povo e essencial à sadia qualidade de vida, impondo-se ao Poder Público e à coletividade o dever de defendê-lo e preservá-lo para as presentes e futuras gerações" (art. 225, caput, da $\mathrm{CRFB} / 88)$.

\section{Na lição de Paulo Bessa de Antunes, com a vigência da Constituição}

Federal, "não se pode mais pensar em tutela ambiental restrita a um único bem, (...) porque o bem jurídico ambiente é complexo. O meio é uma totalidade e só assim pode ser compreendido e estudado".90 91 Ressalta-se o uso, no texto constitucional, do pronome indefinido todos, que amplia a abrangência dos titulares do direito subjetivo, tornandoo de titularidade coletiva, caracterizando-se, assim, como um direito difuso, também conhecido como direito de terceira geração. ${ }^{92}$.

\footnotetext{
${ }^{90}$ ANTUNES, Paulo de Bessa. Direito Ambiental. 14 a ed. São Paulo: Atlas, 2012. p.65.

${ }^{91}$ Para lidar adequadamente com um bem jurídico complexo, como o meio ambiente, é preciso desenvolver um pensamento complexo. Acerca do pensamento complexo, Edgar Morin afirma ser "necessário desfazer duas ilusões que desviam as mentes do problema do pensamento complexo. A primeira é acreditar que a conduz à eliminação da simplicidade. A complexidade surge, é verdade, lá onde o pensamento simplificador falha, mas ela integra em si tudo o que põe ordem, clareza, distinção, precisão no conhecimento. Enquanto o pensamento simplificador desintegra a complexidade do real, o pensamento complexo integra o mais possível os modos simplificadores de pensar, mas recusa as consequências mutiladoras, redutoras, unidimensionais e finalmente ofuscantes de uma simplificação que se considera reflexo do que há de real na realidade. A segunda ilusão é confundir complexidade e completude. É verdade, a ambição do pensamento complexo é dar conta das articulações entre os campos disciplinares que são desmembrados pelo pensamento disjuntivo (um dos principais aspectos do pensamento simplificador); este isola o que separa, e oculta tudo o que religa, interage, interfere. Neste sentido, o pensamento complexo aspira ao conhecimento multidimensional. Mas ele sabe desde o começo que o conhecimento completo é impossível: um dos axiomas da complexidade é a impossibilidade, mesmo em teoria, de uma onisciência. (...) Ele implica o reconhecimento de um principio de incompletude e de incerteza. Mas traz também em seu princípio $\mathrm{p}$ reconhecimento dos laços entre as entidades que nosso pensamento deve necessariamente distinguir, mas não isolar umas das outras. (...) $\mathrm{O}$ pensamento complexo também é animado por uma tensão permanente entre a aspiração de um saber não fragmentado, não compartimentado, não redutor e o reconhecimento do inacabado e da incompletude de qualquer conhecimento". MORIN, Edgar. Introdução ao pensamento complexo. $4^{\mathrm{a}}$ ed. Porto Alegre: Sulina, 2011.p.7.

${ }^{2}$ Em 1995, no julgamento do MS 22164 / SP - SÃO PAULO, o STF, sob a relatoria do Ministro Celso de Mello, entendeu o direito ao meio ambiente ecologicamente equilibrado como um direito de terceira geração.

"A questão do direito ao meio ambiente ecologicamente equilibrado - direito de terceira geração princípio da solidariedade. - o direito a integridade do meio ambiente - típico direito de terceira geração - constitui prerrogativa jurídica de titularidade coletiva, refletindo, dentro do processo de afirmação dos direitos humanos, a expressão significativa de um poder atribuído, não ao individuo identificado em sua singularidade, mas, num sentido verdadeiramente mais abrangente, a própria coletividade social. enquanto os direitos de primeira geração (direitos civis e políticos) - que compreendem as liberdades clássicas, negativas ou formais - realçam o princípio da liberdade e os direitos de segunda geração (direitos econômicos, sociais e culturais) - que se identifica com as liberdades positivas, reais ou concretas - acentuam o princípio da igualdade, os direitos de terceira geração, que materializam poderes de titularidade coletiva atribuídos genericamente a todas as
} 
Diante do fato de que o bem-estar individual e coletivo está significativamente comprometido pela degradação ambiental, proteger a qualidade e o equilíbrio do meio ambiente é parte indissociável da teia de proteção da vida humana (art. $5^{\circ}$, caput $_{s}$ da CF). Neste sentido, o artigo $1^{\circ}$, inciso III, dispõe que a dignidade da pessoa humana é um dos fundamentos da República Federativa do Brasil e é a partir dele que se estrutura a tutela integral do meio ambiente no texto constitucional.

Ademais, o texto constitucional faz um chamado à coletividade, firmando seu dever de defender e preservar o meio ambiente de maneira intergeracional. Daqui emergem os fundamentos constitucionais do direito à participação na tutela ambiental, do princípio da participação comunitária e do princípio da solidariedade. ${ }^{93}$ Desta forma, tanto é dever, quanto é direito do povo, participar na defesa do meio ambiente, tendo em vista o dever de solidariedade entre as gerações.

Neste trabalho entende-se que a expressão coletividade, adotada no caput do artigo 225 da Constituição Federal, abrange a sociedade civil ${ }^{94}$, as organizações, não governamentais (ONGS), constituídas em associações e fundações, ${ }^{95}$ e as organizações da sociedade civil de interesse público. ${ }^{96}$

Assim, a coletividade, formalmente, não inclui o Poder Público, visto que o constituinte expressamente separa-os, ao afirmar que a obrigação de proteger o meio ambiente se impõe ao Poder Público e à coletividade. Reputa-se adequada esta previsão, visto que não se pode delegar somente ao Estado o papel isolado de cuidar do meio ambiente, pois, conforme

\footnotetext{
formações sociais, consagram o princípio da solidariedade e constituem um momento importante no processo de desenvolvimento, expansão e reconhecimento dos direitos humanos, caracterizados, enquanto valores fundamentais indisponíveis, pela nota de uma essencial inexauribilidade". Disponível em: http://www.stf.jus.br/portal/jurisprudencia/listarJurisprudencia.asp?s1=\%28MS+terceira+gera\%E7 $\%$ E3o\%29\%2822164\%2ENUME\%2E+OU+22164\%2EACMS\%2E\%29\&base=baseAcordaos\&url =http://tinyurl.com/bparv6y> Acesso em: 20. abr. 2013.

${ }^{93}$ Sobre o principio da solidariedade ver artigo da Maria Celina Bodin de Moraes. MORAES, Maria Celina Bodin de. O Princípio da Solidariedade. In:PEIXINHO, Manoel Messias; GUERRA, Isabella Franco; FILHO, Firly Nascimento. Os princípios da Constituição de 1988. $2^{\mathrm{a}}$ Ed.. Rio de Janeiro: Editora Lumen Júris, 2006. p. 157.

${ }^{94}$ Expressão acolhida pela Constituição Federal no artigo 58, II.

${ }^{9595}$ Conforme artigos 53 a 69 do Código Civil de 2002.

${ }^{96}$ Lei n. 9.790/99.
} 
reconhecimento internacional, essa tarefa só pode ser executada com eficiência quando há cooperação do corpo social.

Quanto a isso, assevera Antonio Herman V. Benjamin que grande avanço se deu quando a coletividade conquistou a divisão das responsabilidades ambientais com o Estado, afirmando que "o triunfo do particular foi trazer a si a parcela do exercício da função ambiental". 97

Assim, algumas das principais marcas da proteção ambiental constitucional são a presença e a atuação da sociedade civil, ao lado do Poder Público, na defesa do meio ambiente ecologicamente equilibrado. Acerca da cidadania ambiental destaca-se a lição de Paulo Affonso Leme Machado:

Vejo a cidadania como ação participativa onde há interesse público ou interesse social. Ser cidadão é sair de sua vida meramente privada e interessar-se pela sociedade de que faz parte e ter direitos e deveres para nela influenciar e decidir. No caso da cidadania ecológica participa-se em defesa de um interesse difuso, tratando-se de exigir 'cuidado público da vida, ${ }^{98}$

Contudo, vale ressaltar que o termo coletividade não deixa claro o papel individual de cada cidadão na tutela ambiental, de modo que o texto constitucional poderia ter acentuado tal desempenho - conforme feito em documentos internacionais já mencionados.

Quanto ao termo meio ambiente ecologicamente equilibrado, o mesmo autor observa que:

O Poder Público e a coletividade deverão defender e preservar o meio ambiente desejado pela Constituição, e não qualquer meio ambiente. $\mathrm{O}$ meio ambiente a ser defendido e preservado é aquele ecologicamente equilibrado. Portanto, descumprem a Constituição tanto o Poder Público como a coletividade quanto permitem ou possibilitam o desequilíbrio do meio ambiente. ${ }^{99}$

A Constituição Federal realça o valor do direito à informação ao impor ao Poder Público o dever de promover "a educação ambiental em todos os níveis de ensino e a conscientização pública para a preservação do meio ambiente" 100 e ao exigir expressamente a publicidade do Estudo de

\footnotetext{
97 BENJAMIN. Antônio Herman V. Dano ambiental: prevenção, reparação e repressão. São Paulo: Ed Revista dos Tribunais, 1993. p.51.

${ }^{98}$ MACHADO, Paulo Affonso Leme. Direito Ambiental Brasileiro. p.161.

${ }^{99}$ MACHADO, Paulo Affonso Leme. Direito Ambiental Brasileiro. p.158.

${ }^{100}$ Art. $225, \S 1^{\circ}$, IV e VI da CRFB/88, respectivamente.
} 
Impacto Ambiental (EIA) - tema que será aprofundado adiante quando se tratar do licenciamento ambiental.

O texto constitucional garantiu, ainda, o direito à informação em seu artigo $5^{\circ}$, inciso XIV, caracterizando-o, assim, como um dos postulados do regime Democrático de Direito. Contudo, caracterizam-se como exceções ao princípio constitucional da publicidade, o sigilo e o segredo industrial e comercial, quando não colocarem em risco o interesse social, a saúde humana e o meio ambiente, devendo, assim, seus pedidos serem expressos e motivados.

Por fim, menciona-se que a Constituição da República Federativa do Brasil consolidou as conquistas relacionadas aos instrumentos judiciais destinados à participação judicial dos cidadãos na tutela do ambiente por meio da expressa previsão destes, consagrando, assim o já aludido Estado Democrático-Participativo. $\mathrm{O}$ texto constitucional prescreveu, como ferramentas para assegurar a defesa judicial da cidadania ambiental, os seguintes mecanismos: a ação popular, ${ }^{101}$ a ação civil pública, ${ }^{102}$ a ação direta de inconstitucionalidade de lei ou ato normativo, ${ }^{103}$ o mandado de segurança coletivo ${ }^{104}$ e o mandado de injunção ${ }^{105}$.

Assim, a Constituição Federal de 1988 é o maior instrumento de salvaguarda do direito humano fundamental ao meio ambiente ecologicamente equilibrado, que deve ser protegido pelo Poder Público e pela coletividade, sendo, para isto, crucial o respeito à previsão constitucional de participação popular e de acesso à informação ambiental.

\subsubsection{Leis infraconstitucionais}

Quanto à previsão legislativa infraconstitucional sobre participação pública na defesa ambiental, vale mencionar que a Lei 10.257/01,

\footnotetext{
${ }^{101}$ Art. $5^{\circ}$, LXXIII, da CRFB/88.

${ }^{102}$ Art. 129 , III, c/c o $§ 1^{\circ}$, da CRFB $/ 88$.

${ }^{103}$ Arts. 102, I, "a", 103 e $125, \S 2^{\circ}$, da CRFB/88.

${ }^{104}$ Art. $5^{\circ}$, LXX, da CRFB/88 e Lei n. 12.016/09.

${ }^{105}$ Art. $5^{\circ}$, LXXI, da CRFB/88.
} 
conhecida como o Estatuto da Cidade e que institui a Política Nacional Urbana.

A referida lei prevê a necessidade e, inclusive, a obrigatoriedade, da participação da sociedade civil nos debates e nas tomadas de decisão em matéria ambiental. Por exemplo, ao versar sobre o Plano Diretor, em seu artigo $40, \S 4^{\circ}$, inciso I, é prescrita "a promoção de audiências públicas e debates com a participação da população e de associações representativas dos vários segmentos da comunidade".

Já no que tange à legislação infraconstitucional sobre transparência e acesso à informação, em 2003, a Lei n. $10.650^{106}$ dispôs sobre o acesso público aos dados e informações existentes nos órgãos e entidades integrantes do Sistema Nacional do Meio Ambiente - SISNAMA, também instituído pela PNMA. De fato, o referido diploma, garantiu a qualquer indivíduo, independentemente da comprovação de interesse específico, o acesso às informações ambientais. ${ }^{107}$

Exige a lei, em seu artigo $4^{\circ}$, caput, incisos e parágrafo primeiro, a publicação em Diário Oficial e, dentro do prazo de trinta dias subsequentes, a disponibilização, no respectivo órgão, em local de fácil acesso ao público, das listagens e relações contendo informações acerca dos seguintes assuntos:

a) Pedidos de licenciamento, sua renovação e a respectiva concessão;

b) Pedidos e licenças para supressão de vegetação;

\footnotetext{
106 Nos termos do artigo $2^{\circ}$ desta lei: Os órgãos e entidades da Administração Pública, direta, indireta e fundacional, integrantes do Sisnama, ficam obrigados a permitir o acesso público aos documentos, expedientes e processos administrativos que tratem de matéria ambiental e a fornecer todas as informações ambientais que estejam sob sua guarda, em meio escrito, visual, sonoro ou eletrônico, especialmente as relativas a: I - qualidade do meio ambiente; II - políticas, planos e programas potencialmente causadores de impacto ambiental; III - resultados de monitoramento e auditoria nos sistemas de controle de poluição e de atividades potencialmente poluidoras, bem como de planos e ações de recuperação de áreas degradadas; IV - acidentes, situações de risco ou de emergência ambientais; V - emissões de efluentes líquidos e gasosos, e produção de resíduos sólidos; VI - substâncias tóxicas e perigosas; VII - diversidade biológica; VIII - organismos geneticamente modificados.

${ }^{107} \mathrm{O}$ requerimento deverá ser feito por escrito e o interessado assumirá a "obrigação de não utilizar as informações colhidas para fins comerciais, sob as penas da lei civil, penal, de direito autoral e de propriedade industrial, assim como de citar as fontes, caso, por qualquer meio, venha a divulgar os aludidos dados" (art. $2^{\circ}$, $\S 1^{\circ}$, da Lei n. 10.650/03).
} 
c) Autos de infrações e respectivas penalidades impostas pelos órgãos ambientais;

d) Lavratura de termos de compromisso de ajustamento de conduta;

e) Reincidências em infrações ambientais;

f) Recursos interpostos em processo administrativo ambiental e respectivas decisões;

g) Registro de apresentação de estudos de impacto ambiental e sua aprovação ou rejeição.

Percebe-se que a aludida lei foi essencial para tratar especificamente do acesso à informação ambiental, instrumentalizando mecanismos de garantia desse direito e possibilitando, assim, a participação democrática na tutela do meio ambiente ecologicamente equilibrado.

Nota-se, ainda, a Lei n. 12.527/11, é um marco na regulação o acesso à informação, pois dispõe sobre os procedimentos a serem observados pela Administração Pública na garantia do direito de todos os cidadãos à informação, dentre as quais se inclui as relacionadas à proteção do meio ambiente.

Diante do exposto, conclui-se que o cidadão bem informado e com legitimidade para atuar na tutela ambiental legislativa, administrativa e judicial, dispõe de valiosíssimas ferramentas de cidadania e controle social do Poder Público em matéria ambiental.

\subsection{Participação pública e acesso à informação nos procedimentos de licenciamento ambiental}

$\mathrm{Na}$ atualidade, conforme demonstrado, a participação popular e o acesso à informação em matéria ambiental significam a possibilidade que os cidadãos têm de, individualmente, reunidos em grupos ou representados por entes habilitados, tomar parte nas instâncias de decisão relacionadas ao tema e de exercer o controle sobre as omissões e atividades públicas e privadas potencial ou efetivamente lesivas ao meio ambiente. 
É neste contexto que se insere o direito à participação e à informação no procedimento do licenciamento ambiental de atividades ou empreendimentos potencialmente causadores de significativa degradação ao meio ambiente.

A aludida PNMA é o marco legislativo federal da consolidação do licenciamento ambiental como um dos principais institutos de proteção e preservação do meio ambiente em âmbito nacional, tendo sido previsto, ao lado da avaliação de impactos ambientais, como instrumentos administrativos ambientais autônomos (artigo $9^{\circ}$, incisos III e IV, respectivamente). Um dos aspectos mais importantes do licenciamento ambiental como ferramenta de proteção do meio ambiente é a possibilidade de participação popular e o seu acesso às informações deste procedimento $^{.108}$

Antes deste trabalho se debruçar sobre a análise do direito à participação e à informação no bojo do licenciamento ambiental, faz-se necessário, sucintamente, esclarecer os conceitos de licenciamento ambiental e do EIA.

O licenciamento ambiental é conceituado como sendo:

$\mathrm{O}$ procedimento administrativo destinado a licenciar atividades ou empreendimentos utilizadores de recursos ambientais, efetiva ou potencialmente poluidores ou capazes, sob qualquer forma, de causar degradação ambiental. ${ }^{109}$

Este é exigido como condição para "a construção, instalação, ampliação e funcionamento" daquelas atividades e empreendimentos. ${ }^{110}$ Desta forma, tal procedimento é obrigatório para atividades ou empreendimentos que utilizem recursos naturais, de forma efetiva ou potencialmente poluidora ou capaz de causar degradação ambiental.

Como se vê, o licenciamento ambiental é um procedimento administrativo de gestão ambiental, na medida em que, por meio dele, o

\footnotetext{
${ }^{108}$ NETO, Nicolao Dino de Castro e Costa. Proteção Jurídica do Meio Ambiente. Belo Horinzonte: Editora Del Rey, 2003. p 39.

${ }^{109}$ Art. $1^{\circ}$, inciso I da Lei Complementar n ${ }^{\circ}$ 140/11 (LC 140/11). A LC 140/11 versa, dentre outros temas, sobre a repartição da competência administrativa ambiental dos entes federados e o licenciamento ambiental.

${ }^{110}$ Art. 10, caput, da PNMA, já com nova redação dada pela LC 140/11.
} 
Poder Executivo controla as interferências humanas no meio ambiente, buscando concretizar o princípio do desenvolvimento sustentável. ${ }^{111}$

Neste passo, de acordo com Celso Antônio Bandeira de Mello, como todo procedimento administrativo, o licenciamento é visto como "uma sucessão itinerária e encadeada de atos administrativos que tendem, todos, a um resultado final e conclusivo". ${ }^{112}$

Assim, o licenciamento ambiental se sujeita aos princípios constitucionais que norteiam a atividade administrativa, quais sejam, legalidade, impessoalidade, moralidade, publicidade e eficiência, ${ }^{113}$ bem como aos princípios legais da finalidade, motivação, razoabilidade e proporcionalidade, da ampla defesa e do contraditório, da segurança jurídica e do interesse público. ${ }^{114}$

O licenciamento ambiental, como procedimento administrativo que se vincula à proteção do meio ambiente ecologicamente equilibrado, bem jurídico difuso e direito fundamental, sempre será público, isto é, aberto à participação e ao acesso à informação por parte da população. Em outras palavras, o licenciamento deverá sempre ser público ainda que não sejam significativos os impactos ambientais das atividades ou empreendimentos utilizadores de recursos ambientais, efetiva ou potencialmente poluidores ou capazes, sob qualquer forma, de causar degradação ambiental.

Acerca do EIA, quando a obra ou atividade for potencialmente causadora de significativa degradação ambiental, no curso do licenciamento ambiental deve-se elaborar previamente este estudo. Como instrumento preventivo de danos e para que seja atingida a sua finalidade, deve o EIA ser anterior à decisão do Poder Público sobre a licença prévia. ${ }^{115}$ Não é por

\footnotetext{
${ }^{111}$ MILARÉ, Édis. Direito do Ambiente. p 511

112 MELLO, Celso Antônio Bandeira de. Curso de Direito Administrativo. 28 ed. São Paulo: Malheiros, 2011, p. 491.

${ }^{113}$ Art. 37, caput, da CRFB/88.

${ }_{114}^{114}$ Art. $2^{\circ}$ da Lei n. 9.784/99 - somente aplicável em âmbito federal.

${ }^{115}$ Em relação às fases do licenciamento ambiental, são três as licenças ambientais que podem ser expedidas no final de cada fase do procedimento, quais sejam: a licença prévia (LP), a licença de instalação (LI) e a licença de operação (LO). Na primeira fase do licenciamento ambiental prévio ocorre o planejamento do empreendimento ou atividade, na qual se avaliam a localização e a concepção deste, além de se atestar, ou não, sua viabilidade ambiental, com o estabelecimento dos
} 
outra razão que a Constituição Federal lhe dá o nome de "estudo prévio de impacto ambiental". 116

Como uma das missões do EIA é informar à população os impactos ambientais a serem causados, faz-se necessário que este receba ampla publicidade e que os interessados possam se manifestar antes da decisão administrativa de outorga da licença ambiental para a implementação de obras ou atividades com significativo impacto ambiental. A Constituição da República Federativa do Brasil de 1988 é clara ao exigir que se dê publicidade ao EIA, ${ }^{117}$ estando sujeito à responsabilização aquele que negar informação sobre o referido procedimento - salvo as hipóteses excepcionais adiante analisadas. ${ }^{118}$

Ademais, o EIA deve sempre ser acompanhado de seu Relatório de Impacto Ambiental (RIMA), como condição para a emissão da licença prévia. $^{119}$ Ambos os estudos são regulamentados pela Resolução

requisitos básicos e condicionantes a serem atendidos nas próximas fases. Concedida a LP, será por meio da LI que se autoriza a instalação do empreendimento ou atividade, de acordo com as especificações dos planos, programas e projetos aprovados, incluindo as medidas de controle ambiental, entre outras condicionantes, da qual constituem motivo determinante. Por fim, ao término do procedimento, já tendo sido expedidas as primeiras duas licenças, será emitida a LO, por meio da qual se autoriza o início da operação da atividade ou empreendimento, após a verificação pelo órgão ambiental do efetivo cumprimento das prescrições e exigências constantes das licenças anteriores, com as medidas de controle ambiental e condicionantes determinados para a operação (Art. $8^{\circ}$, inciso III da Resolução CONAMA n. 237/97).

116 O EIA foi consagrado pela Constituição Federal como nome de Estudo Prévio de Impacto Ambiental, por isso, alguns autores, como Paulo Affonso Leme Machado, usam a sigla EPIA para designá-lo. MACHADO, Paulo Affonso Leme. Direito Ambiental Brasileiro. $20^{\text {a }}$ ed rev., atual. e ampl. São Paulo: Malheiros Editores, 2012. p 263.

${ }_{117}$ Arts. $5^{\circ}$, inciso XXXIV e $225, \S 1^{\circ}$, inciso IV da CRFB/88.

118 Além disso, a Lei federal 9.605/98 tipifica o crime de "elaborar ou apresentar, no licenciamento, concessão florestal ou qualquer outro procedimento administrativo, estudo, laudo ou relatório ambiental total ou parcialmente falso ou enganoso, inclusive por omissão" (art. 69A).

119 Acerca do EIA/RIMA, o Instituto Estadual de Meio Ambiente do Estado do Rio de Janeiro (INEA) esclarece que "o EIA é um conjunto de relatórios técnicos destinado a instruir o processo de licenciamento. Os relatórios são elaborados por equipe multidisciplinar, habilitada e independente, com base em Instruções Técnicas (IT) específicas elaboradas pelo INEA. O RIMA deve reproduzir as conclusões do EIA, mas como é destinado à informação e ao esclarecimento do público comum (leigo), principalmente dos habitantes da área de influência do empreendimento, deve ser redigido em linguagem clara e objetiva, e informar os impactos, positivos e negativos, que a implantação do empreendimento terá sobre o meio ambiente natural, social e cultural. Os Estudos de Impacto Ambiental e o Relatório de Impacto Ambiental (EIA/RIMA) devem, a partir de um diagnóstico socioeconômico e ambiental (meios físico e biótico) de toda a área que será afetada, realizar um prognóstico das consequências do empreendimento, e sugerir medidas, na forma de pré-projetos, com o objetivo de minimizar os impactos considerados negativos e maximizar aqueles considerados positivos. Embora tenham finalidades diversas, EIA e RIMA são instrumentos complementares, e por isto são sempre citados em conjunto". Disponível em <http://www.inea.rj.gov.br/fma/eia_rima_apresentacao.asp >. Acesso em: 10. abr. 2013. 
CONAMA n. 01/86, que deve ser interpretada à luz do artigo 225 da Constituição Federal, que determina a publicidade do EIA como um todo.

O RIMA deve refletir as conclusões do EIA e ser apresentado de forma objetiva e em linguagem acessível para a adequada compreensão de suas informações por todos os interessados, muitas vezes leigos sobre a temática ambiental. Neste sentido, afirma Paulo de Bessa Antunes que o RIMA "é parte integrante do EIA e tem por finalidade fazer com que conceitos técnicos e científicos sejam acessíveis à população em geral”. ${ }^{120}$

Para que a participação pública no licenciamento ambiental seja eficaz, é indispensável que o legislador preveja prazos razoáveis, ${ }^{121}$ permitindo, assim, que os interessados possam se preparar para intervir tempestiva e fundamentadamente nos processos decisórios, sob pena de ser afetada a legalidade do procedimento.

Vale ressaltar que é a partir da ampla publicidade dos requerimentos e concessões de licenças ambientais que se viabiliza o acompanhamento e a intervenção do público em cada fase do licenciamento, a fim de apresentarem pleitos concernentes à defesa ambiental. Uma das finalidades da publicidade é dar real transparência aos atos e procedimentos administrativos, possibilitando a participação popular nas decisões públicas do licenciamento ambiental. ${ }^{122}$

Quanto ao público que opina no EIA, pode-se afirmar que não há exigência de cidadania brasileira para expressar manifestações, questionamentos e demandas, de modo que tanto nacionais quanto estrangeiros estão habilitados a participarem no licenciamento ambiental. ${ }^{123}$

Em relação aos meios de divulgação, os pedidos de licenciamento e sua concessão, bem como a respectiva renovação deverão ser publicados no jornal oficial, em periódico regional ou local de grande circulação, ou em meio eletrônico de comunicação mantido pelo órgão ambiental

\footnotetext{
${ }^{120}$ ANTUNES, Paulo de Bessa. Direito Ambiental. p.399.

${ }^{121}$ MIRRA, Álvaro Luiz Valery. Participação, processo civil e defesa do meio ambiente. $\mathrm{p} 157$.

122 MACHADO, Paulo Affonso Leme. Direito Ambiental Brasileiro.p 248; MILARÉ, Édis. Direito do Ambiente. p. 232.
} 
competente. $^{124}$ Além disso, deverão ser publicadas as seguintes informações de interesse público: a decisão sobre a determinação do EIA, o registro de apresentação e da aprovação ou rejeição do EIA ${ }^{125}$ e qualquer modelo de requerimento de licença, os quais devem ser publicados em periódico e no Diário Oficial. ${ }^{126}$ As únicas exceções a estas regras são as hipóteses de sigilo ou segredo industrial.

Ademais, as cópias do EIA ficam à disposição dos interessados, nos centros de documentação ou bibliotecas do IBAMA e do órgão estadual de controle ambiental correspondente, mesmo no período de análise técnica. ${ }^{127}$ Caso o licenciamento ambiental esteja a cargo de órgão ambiental municipal, o EIA ficará disponível para acesso da população nas bibliotecas e centros de documentação municipais existentes. ${ }^{128}$ Vale mencionar que aqueles órgãos públicos que manifestarem interesse, ou tiverem relação direta com a atividade ou empreendimento a ser licenciado, receberão cópia do EIA, para conhecimento e manifestação. ${ }^{129}$

O cumprimento destas normas é essencial para a legalidade do EIA. Desta forma, o legislador brasileiro buscou viabilizar que a população acompanhasse as informações sobre as interferências que as atividades e empreendimentos a serem licenciados terão na qualidade ambiental do meio em questão. Contudo, questiona-se a real possibilidade de acesso à informação em matéria ambiental por meio da exigência formal de publicação em Diário Oficial, visto que este meio de comunicação não alcança a grande massa da população brasileira.

Quanto aos casos de sigilo ou segredo industrial, trata-se de exceções ao princípio da publicidade administrativa que são aceitas pelo ordenamento jurídico, quando devidamente solicitados e motivados pelo

\footnotetext{
${ }^{123}$ MACHADO, Paulo Affonso Leme. Direito Ambiental Brasileiro. p. 295.

${ }^{124}$ Art. $10, \S 1^{\circ}$ da Lei n. 6.938/81.

${ }^{125}$ Art. $4^{\circ}$, I e VII da Lei n. 10.650/03. No mesmo sentido estão as disposições legais do Decreto n. 99.271/90 (art. 17, §4 ) e da Resolução CONAMA n. $237 / 97$ (art. 10, II e VIII).

${ }^{126}$ A Resolução CONAMA n. 06/86 instrui como deverá ser feita a publicação.

${ }^{127}$ Art. 11, caput, da Resolução CONAMA n. 01/86.

${ }^{128}$ MACHADO, Paulo Affonso Leme. Direito Ambiental Brasileiro. $20^{\mathrm{a}} \mathrm{ed}$ rev., atual. e ampl. São Paulo: Malheiros Editores, 2012.p 299.
} 
interessado, de modo que se permite a não publicidade do EIA. ${ }^{130}$ Sobre estas exceções à publicidade do licenciamento ambiental - procedimento de interesse geral - Paulo Affonso Leme Machado aduz que "cabe sempre ao órgão público informar os motivos da autorização da existência de um segredo". 131

Note-se que sem a publicidade do licenciamento ambiental as licenças expedidas ao longo do processo não podem produzir efeitos. Contudo, não pode ser a publicidade elevada à mera condição de ato formal, devendo esta ser efetiva e rotineira como condição de legalidade da decisão pública em matéria ambiental. ${ }^{132}$

Sem dúvidas, a efetiva publicidade é imperiosa para o diálogo entre a sociedade e o Poder Público, assim como é ferramenta indispensável para o empoderamento popular. Sherry R. Arnstein defende que somente se pode falar no termo participação pública quando há empoderamento popular, ou seja, a opinião da sociedade civil é, de fato, incorporada na decisão pública e/ou privada. ${ }^{133}$

No que diz respeito à participação pública, propriamente dita, no licenciamento ambiental, o legislador brasileiro previu a possibilidade de intervenção da sociedade tanto por meio de comentários, quanto pela participação em audiências públicas. ${ }^{134}$

Neste cenário, são possíveis três momentos de participação popular ao longo do licenciamento ambiental, quais sejam: (i) nos comentários ao EIA, (ii) em audiências públicas relacionados com a elaboração, discussão e aprovação do respectivo EIA, e (iii) nos comentários e solicitações decorrentes daquela audiência pública. ${ }^{135} 136$

\footnotetext{
${ }^{129}$ Art. $11, \S 1^{\text {o }}$ da Resolução CONAMA n. 01/86.

${ }^{130}$ Art. 11, caput, da Resolução CONAMA n. 01/86.

${ }^{131}$ MACHADO, Paulo Affonso Leme. Direito à informação e meio ambiente. p.264.

132 MEIRELLES, Hely Lopes. Direito Administrativo brasileiro. $23^{\mathrm{a}}$ ed., atual. São Paulo: Malheiros Editores, 1998. p. 81-83.

133 ARNSTEIN, Sherry R. A Ladder of Citizen Participation. p. 216-224.

${ }^{134}$ Art. 11, § $2^{\circ}$ da Resolução CONAMA n. 01/86.

$135 \mathrm{O}$ art. 10 da Resolução CONAMA n. 237/97, definiu os procedimentos do licenciamento ambiental, prevendo as seguintes etapas : (...) IV - Solicitação de esclarecimentos e complementações pelo órgão ambiental competente, integrante do SISNAMA, uma única vez, em
} 
A fase de comentários do EIA se inicia quando o documento estiver acessível ao público num centro de documentação do órgão ambiental competente. Esta intervenção no licenciamento ambiental por meio de comentários ao EIA, pode ser feita por uma ampla gama de interessados como, por exemplo, qualquer pessoa (nacional ou estrangeira), pelas associações ambientalistas (ao contrário da ação civil pública, aqui não se exige que elas estejam constituídas há mais de um ano), por associações não ambientalistas, por sindicatos, por universidades, por partidos políticos, pelo Ministério Público e organismos da Administração Pública direta e indireta das três esferas (federal, estadual e municipal). ${ }^{137}$

Em âmbito federal, não há previsão legislativa sobre a duração da fase de comentários ao EIA, de modo que cada estado da federação dispõe sobre a matéria em legislação especifica. Sobre isso, Paulo Affonso Leme Machado afirma que "nenhum Estudo de Impacto criterioso e não superficial será feito num período menor do que trinta dias". ${ }^{138}$

Pode até ser que os comentários concernentes ao EIA não existam devido à ausência de participação pública, entretanto, para que o procedimento seja revestido de legalidade é preciso que haja a possibilidade de serem emitidas opiniões e solicitações por parte da população - que não inclua o propronente do projeto, a equipe multidisciplinar e a Administração Pública.

\footnotetext{
decorrência da análise dos documentos, projetos e estudos ambientais apresentados, quando couber, podendo haver a reiteração da mesma solicitação caso os esclarecimentos e complementações não tenham sido satisfatórios (inciso IV); V - Audiência pública, quando couber, de acordo com a regulamentação pertinente; VI - Solicitação de esclarecimentos e complementações pelo órgão ambiental competente, decorrentes de audiências públicas, quando couber, podendo haver reiteração da solicitação quando os esclarecimentos e complementações não tenham sido satisfatórios; (...).

${ }^{136}$ Contudo, vale mencionar que nada impede a realização de audiências públicas convocadas por parte dos órgãos administrativos ambientais, para a discussão de qualquer projeto ambientalmente relevante, de modo que, a participação popular se dê em contextos fora do licenciamento ambiental ou da discussão do EIA, como por exemplo, na formulação e execução de programas de ação e políticas públicas. Este é o entendimento de Rachel Biderman Furriela. FURRIELA, Rachel Biderman. Democracia, cidadania e proteção ao meio ambiente. p. 100.

${ }^{137}$ MACHADO, Paulo Affonso Leme. Direito Ambiental Brasileiro. p 295 e 300.

${ }^{138}$ MACHADO, Paulo Affonso Leme. Direito Ambiental Brasileiro. p 302.
} 
Devido à relevância para este trabalho da participação popular em audiências públicas nos licenciamento ambientais, sua análise será destacada e aprofundada adiante.

Assim, por tudo acima exposto, percebe-se que a legislação brasileira dispõe sobre a possibilidade de acesso à informação e participação popular no licenciamento ambiental, prevendo que esta ocorra de modo efetivo em relação à execução de obras e atividades que impactam o meio ambiente, tanto via comentários, aqui considerados, quanto via audiências públicas, analisadas a seguir.

\subsubsection{Audiências públicas nos licenciamentos ambientais}

Uma vez contextualizada a realização da audiência pública no âmbito do licenciamento ambiental, inicialmente, este trabalho se propõe a realizar uma breve análise de quatro aspectos que definem a relevância do instituto, quais sejam:

a) Suas finalidades:

b) A obrigatoriedade da convocação da audiência pública pelo órgão ambiental competente nos licenciamentos de empreendimentos que exigem o EIA;

c) O resultado audiência pública; e

d) $\mathrm{O}$ momento adequado para a realização desta etapa do procedimento. Na seqüência, serão abordadas outras características importantes da audiência pública, tais como a qualificação dos legitimados, o número de audiências públicas, a publicidade do EIA, entre outros.

Ao longo do presente trabalho será analisada a legislação concernente a este instituto e sua interpretação conforme a Constituição Federal.

O primeiro aspecto a ser analisado são as finalidades da audiência pública. Em sentido amplo, este instrumento tem o fito de valorizar aqueles 
que se interessam em agir pedindo a audiência ${ }^{139}$. Em outras palavras, existem duas formas de audição coexistindo neste momento democrático do licenciamento ambiental. Por um lado, a população exercita sua audição ao receber informações do Poder Público e do empreendedor sobre a atividade a ser licenciada e seu respectivo EIA. Por outro lado, o Poder Público e o empreendedor exercitam suas audições ao receberem as manifestações da população sobre os impactos decorrentes da atividade, além dos questionamentos acerca da decisão de permissão daquela. Desta forma, percebe-se que um dos objetivos da audiência pública em matéria ambiental - e não o único - é criar um canal de comunicação e fomentar o diálogo entre o empreendedor, a Administração Pública e a população interessada.

Além disso, outra finalidade do instituto é o empoderamento da sociedade civil - naquela acepção de Sherry R. Arsntein - sobre as decisões públicas ambientais, possibilitando que a população, através da sua participação informada, influencie na discussão acerca da viabilidade do empreendimento a ser licenciado.

Neste passo, não se deve confundir audiência pública com sessão pública. Como esclarece Karla da Silva Costa Batista ao comentar a diferença entre a sessão e a audiência pública "para que seja uma audiência é imprescindível a efetiva participação popular". ${ }^{140}$

Da mesma forma, de acordo com a lição de Maria Goretti Dal Bosco, não se confunde a sessão pública com a reunião popular, que teria dado origem a atual audiência pública, destacando, sua finalidade legitimadora das decisões públicas. ${ }^{141}$

Assim, em sentido estrito, a audiência pública tem o fim de legalizar e legitimar o licenciamento ambiental, através da incorporação das manifestações populares às decisões públicas.

\footnotetext{
${ }^{139}$ MACHADO, Paulo Affonso Leme. Direito Ambiental Brasileiro. p. 306.

140 BATISTA, Karla da Silva Costa. Verbete Audiência Pública. In: CASTRO, Carmem Lúcia Freitas de; GONTIJO, Cynthia Rúbia Braga; AMABILE, Antônio Eduardo de Noronha (orgs.) Dicionário de Políticas Públicas. Barbacena: Editora da Universida do Estado de Minas Gerais, 2012. p. 31-33.
} 
Neste ponto, vale analisar as normas que disciplinam a audiência pública nos licenciamentos ambientais em âmbito federal, quando afirmam que o órgão ambiental promoverá a realização da audiência pública para informação sobre o projeto e seus impactos ambientais e discussão do RIMA ${ }^{142}$ e "expor aos interessados o conteúdo do produto em análise e do seu referido RIMA, dirimindo dúvidas e recolhendo dos presentes as críticas e sugestões a respeito". ${ }^{143}$

A análise que se faz sobre estes dispositivos objetiva criticar a fixação do conteúdo da audiência pública e, sobretudo, a limitação da sua finalidade. Assim, ao prescrever que a finalidade da audiência pública é ser um ambiente de comunicação entre as partes, retirou-se deste instituto o que este trabalho entende como sendo seu maior atributo, isto é, a capacidade real de influência popular nas decisões do Poder Público. Desta forma se limitou a audiência pública à condição de mecanismo de transmissão de informação, sendo que o conteúdo desta é pré-fixado. ${ }^{144}$

Destaca-se que tais normas foram editadas antes de 1988, portanto, suas interpretações devem ser feitas à luz da Constituição Federal (art. 225, $\S 1^{\circ}$, IV). Sendo assim, tanto o EIA quanto o RIMA, de atividades ou empreendimentos potencialmente causadores de significativa degradação ambiental, devem ser analisados em audiência pública, respeitados os já mencionados segredos e sigilos industriais.

Conclui-se, então, que a audiência pública tem como finalidade última a garantia da efetividade dos princípios democráticos inerentes ao Direito Ambiental, constituindo-se como um importante instrumento para a defesa do meio ambiente.

\footnotetext{
${ }^{141}$ DAL BOSCO, Maria Goretti. Audiência Pública como Direito de Participação. In: Revista dos Tribunais. Vol. 809. São Paulo: Editoria Revista dos Tribunais, 2003. p. 727-739.

${ }^{142}$ Art. 11, §2 da Resolução CONAMA n. 01/86.

${ }^{143}$ Art. $1^{\circ}$ da Resolução CONAMA n. 09/87.

144 FINK, Daniel Roberto. Audiência Pública em matéria ambiental no Direito brasileiro. In: Revista dos Tribunais. Vol. 695. São Paulo: Editora Revista dos Tribunais, 1993. p.2.
} 
O segundo aspecto versa sobre a obrigatoriedade da convocação da audiência pública pelo órgão ambiental competente nos licenciamentos de empreendimentos que exigem o EIA.

Em âmbito federal, as normas que disciplinam as audiências públicas no bojo do licenciamento ambiental, dispõem que a audiência pública será cabível de acordo com a regulamentação pertinente. As normas indicam que as audiências públicas somente serão promovidas quando o órgão ambiental competente as reputar necessárias, tal como previsto no artigo 10, inciso V, da Resolução CONAMA n. 237/97, no artigo 11, § $2^{\circ}$ da Resolução CONAMA n. 01/86 ${ }^{145}$ e no artigo $2^{\circ}$, caput da Resolução CONAMA n. 09/87. ${ }^{146}$

Além disso, afirma-se ser a audiência pública obrigatória quando solicitada por iniciativa do Ministério Público, por cinquenta ou mais cidadãos ou por entidade civil. ${ }^{147}$ Nota-se que esta convocação de audiência pública não pode ser negada ou obstruída pelos órgãos públicos, por se tratar de direito subjetivo público. Inclusive, a violação de tal direito, que é líquido e certo, configura hipótese de cabimento de mandado de segurança.

Percebe-se que as referidas normas federais não reputam como obrigatória a convocação das audiências públicas nos licenciamentos ambientais que exigem EIA, posto que esta será realizada sempre que o órgão ambiental a julgar necessária, ou quando o parquet ou cinquenta cidadãos a solicitarem. ${ }^{148}$

\footnotetext{
${ }^{145}$ Art. 11, § $2^{\circ}$ da Resolução CONAMA n. 01/86: "Ao determinar a execução do estudo de impacto ambiental e apresentação do RIMA, o estadual competente ou o IBAMA ou, quando couber o Município, determinará o prazo para recebimento dos comentários a serem feitos pelos órgãos públicos e demais interessados e, sempre que julgar necessário, promoverá a realização de audiência pública para informação sobre o projeto e seus impactos ambientais e discussão do RIMA".

${ }^{146,}$ Art. $2^{\circ}$, caput da Resolução CONAMA n. 09/87: "Sempre que julgar necessário, ou quando for solicitado pôr entidade civil, pelo Ministério Público, ou por 50 (cinqüenta) ou mais cidadãos, o Órgão do Meio Ambiente promoverá a realização de Audiência Pública”.

${ }^{147}$ Art. $2^{\circ}$, caput da Resolução CONAMA n. 09/87.

${ }^{148}$ Entretanto, apesar do órgão ambiental não ser obrigado a convocar a audiência pública de ofício, está ele obrigado, a partir da data do recebimento do EIA, a fixar em edital e anunciar pela imprensa local a abertura do prazo de, no mínimo, quarenta e cinco dias para que os interessados solicitem a realização da audiência pública. Art. $2^{\circ}, \S^{\circ}{ }^{\circ}$ da Resolução CONAMA n. 09/87.
} 
Uma parte da doutrina ambiental, representada por autores renomados como Édis Milaré, ${ }^{149}$ Paulo Affonso Leme Machado ${ }^{150}$ e Paulo de Bessa Antunes, ${ }^{151}$ não se manifesta claramente sobre o tema, apenas reproduzindo o disposto na legislação federal. Tal fato parece revelar que, implicitamente, não se defende a obrigatoriedade de que o órgão público, de ofício, convoque a realização de audiência pública para situações enquadradas naquelas sujeitas ao estudo de impacto ambiental.

Por outro lado, no que diz respeito às hipóteses não enquadradas naquelas sujeitas ao estudo de impacto ambiental, apesar de não existir previsão legislativa sobre a realização de audiências públicas, Álvaro Luiz Valery Mirra defende que:

Não há como desconsiderar a natureza e os fins de referidas reuniões públicas, como mecanismos de informação e consulta da população a respeito de obras, atividades, projetos e empreendimentos suscetíveis de acarretar repercussões de relevo sobre a qualidade ambiental. ${ }^{152}$

Portanto, é possível a convocação desta audiência pública por parte dos órgãos ambientais a fim de que se discuta qualquer projeto ambientalmente relevante, bem como a formulação e implementação de programas de ação e políticas públicas. ${ }^{153}$

Frisa-se que o presente trabalho posiciona-se a favor da obrigatoriedade da realização de audiências públicas, não em todos os casos de licenciamento ambiental, pois assim, se estaria criando um entrave ao desenvolvimento econômico nacional, mas naquelas hipóteses em que o impacto ambiental é significativo e, por isso, se exige a realização do EIA. ${ }^{154}$

Entende-se que esta posição se coaduna com a Constituição Federal quando esta tutela o meio ambiente ecologicamente equilibrado como sendo

\footnotetext{
${ }^{149}$ MILARÉ, Édis. Direito do Ambiente. p 499.

${ }^{150}$ MACHADO, Paulo Affonso Leme. Direito Ambiental Brasileiro. p 304.

${ }^{151}$ ANTUNES, Paulo de Bessa. Direito Ambiental. p.400.

152 MIRRA, Álvaro Luiz Valery. Participação, processo civil e defesa do meio ambiente.p. 163.

${ }^{153}$ MIRRA, Álvaro Luiz Valery. Participação, processo civil e defesa do meio ambiente.p. 163.; FURRIELA, Rachel Biderman. Democracia, cidadania e proteção ao meio ambiente. p.100.

${ }^{154}$ Vale mencionar que em âmbito estadual, a realização de audiências públicas em procedimentos de licenciamento ambiental é obrigatória nos Estados cujas legislações assim prevejam, tal como ocorre no Estado do Rio de Janeiro, conforme dispõe o artigo $3^{\circ}$ da Resolução CONEMA n. 35/11.
} 
um bem difuso e um direito fundamental das atuais e futuras gerações. Neste sentido, afirma José Afonso da Silva que "a participação popular no procedimento de estudo ambiental é uma exigência da natureza mesma do patrimônio ambiental". ${ }^{155}$

Ademais, o constituinte expressamente afirma que deverá se dar publicidade ao EIA, devendo esta ser compreendida em seu sentido amplo, o qual abrange a participação pública (art. 225, caput e $\S^{\circ}$, IV).

Assim, ao afirmar que audiência pública depende de um juízo de discricionariedade do órgão público ambiental ou de solicitação do Ministério Público ou um grupo de cidadãos, limitou-se a possibilidade da população intervir antes da validação final do EIA, por meio de críticas e solicitações de esclarecimentos, o que, por si só, à luz do Estado Democrático-Participativo que consagra o princípio da participação comunitária $^{156,}$ levanta críticas acerca da constitucionalidade destes dispositivos.

Ressalta-se, ainda, que a realização de audiência pública não é só uma condição para conferir legitimidade ao licenciamento ambiental, mas também para the revestir de legalidade. Neste sentido, a legislação expressamente dispõe que a licença não terá validade na hipótese de haver solicitação de audiência pública e o órgão ambiental competente não realizá-la. ${ }^{157}$

Portanto, diante da relevância do instituto da audiência pública, deve esta ser realizada sem restrições, afinal não representa nenhum risco ao meio ambiente, pelo contrário, configura instrumento de sua proteção. Assim, tentativas de impedir-lhe a realização atentam contra o princípio democrático, abrindo espaço para àqueles que visam manter a sociedade desinformada e distante das decisões públicas, limitar a livre-iniciativa e, com isso, obstruir o desenvolvimento sustentável do Brasil.

\footnotetext{
${ }^{155}$ SILVA, José Afonso da. Direito Ambiental Constitucional. p. 300.

${ }^{156}$ NETO, Nicolao Dino de Castro e Costa. Proteção Jurídica do Meio Ambiente. p. 39-47.

${ }^{157}$ Art. $2^{\circ}, \S 2^{\circ}$ da Resolução CONAMA n. 09/87.
} 
O terceiro aspecto a ser analisado é o resultado audiência pública. Neste momento, se analisará se o caráter da audiência é consultivo ou decisório (ou deliberativo).

A legislação prevê que a ata da audiência pública e seus anexos, servirão de base, juntamente com o RIMA, para a análise e parecer final do órgão licenciador quanto à aprovação ou não do projeto. ${ }^{158}$ Note-se que, ao afirmar que o resultado do evento servirá como base para a decisão do órgão licenciador, não foi estabelecido se as demandas populares expressas na audiência pública são consultivas ou deliberativas. ${ }^{159}$ Em outras palavras, a legislação federal não é clara quanto à obrigatoriedade do resultado da audiência pública objetivamente influenciar a decisão do administrador público.

Neste passo, os autores debatem sobre o caráter deliberativo ou consultivo das audiências públicas no âmbito do licenciamento ambiental.

$\mathrm{Na}$ corrente que defende que o caráter deliberativo do resultado da audiência pública está a posição de Gustavo Henrique Justino que afirma que só há o efeito vinculativo quando as audiências são realizadas na fase decisória do procedimento. ${ }^{160}$

Posição diferente é defendida por Edilson Pereira Nobre Junior ao afirmar que "o fato de a audiência pública vir a lume durante a instrução não autoriza, por si só, o remate de que os seus resultados não vinculem o administrador". ${ }^{161}$

Já a corrente que defende a natureza consultiva do resultado da audiência pública está Édis Milaré e Álvaro Luiz Valery Mirra. O primeiro afirma que se trata de procedimento estritamente consultivo, de forma que, em consonância com a legislação pátria, este evento é o foro adequado para possibilitar que os interessados se informem, questionem, critiquem,

\footnotetext{
${ }^{158}$ Art. $5^{\circ}$ da Resolução CONAMA n. 09/87.

${ }^{159}$ Art. $5^{\circ}$ da Resolução CONAMA n. 09/87.

160 JUSTINO, Gustavo Henrique. Audiências públicas e o processo administrativo brasileiro. In: Revista de Direito Administrativo. Vol. 209. Rio de Janeiro: Editora FGV, 1997. p. 162-163.

${ }^{161}$ NOBRE JÚNIOR, Edilson Pereira. Função Administrativa e Participação Popular. In: Revista dos Tribunais. Vol. 796. São Paulo: Editora Revista dos Tribunais, 2002. p. 104-113.
} 
apoiem entre outras manifestações acerca do empreendimento objeto de licenciamento ambiental. ${ }^{162} \mathrm{Na}$ mesma linha, o segundo autor, afirma ser meramente consultiva a participação da população em audiências públicas ambientais, de modo que não há caráter deliberativo em suas manifestações. ${ }^{163}$

Entre os dois juízos supracitados está a corrente moderada que sustenta que, no Brasil, a natureza dos resultados das audiências públicas deve ser definida pelo legislador. Nessa direção está a lição de Diogo de Figueiredo Moreira Neto sobre a audiência pública, ao aduzir que esta é "um processo administrativo de participação aberto a indivíduos e a grupos sociais determinados que, por sua vez, é criado por lei e lhe preceitua a forma e a eficácia vinculatória". 164

Vale ressaltar que o presente trabalho entende que os resultados produzidos no âmbito da audiência pública são consultivos, devendo, entretanto, ser sempre considerados na motivação da escolha pública, sendo este ponto fundamental para a atribuição de legalidade e legitimidade do ato oficial.

Isto porque, a audiência pública adequadamente relatada em ata, não pode ser desconsiderada pelo órgão licenciador em sua tomada de decisão quanto à expedição de licença ambiental. Tal ato administrativo deverá ser motivado, contendo os argumentos favoráveis ou desfavoráveis ao conteúdo da ata e, respondendo às manifestações, questionamentos e demandas populares expressas na audiência pública, sob pena de nulidade formal do ato administrativo. ${ }^{165}$

Neste sentido, Paulo Affonso Leme Machado ressalta que "de nada adiantaria serem previstos comentários que não fossem suficientemente sopesados e respondidos". 166

\footnotetext{
${ }^{162}$ MILARÉ, Édis. Direito do Ambiente. p. 501 e 502.

${ }^{163}$ MIRRA, Álvaro Luiz Valery. Participação, processo civil e defesa do meio ambiente.p. 163.

164 MOREIRA NETO, Diogo de Figueiredo. Audiências públicas. In: Revista de Direito Administrativo. Vol. 210. Rio de Janeiro: Editora FGV, 1997. p. 11-23.

${ }^{165}$ Art. $2^{\circ}$, caput, da Lei n. 9.784/99.

${ }^{166}$ MACHADO, Paulo Affonso Leme. Direito Ambiental Brasileiro. p. 311.
} 
Desta forma, o processo de tomada de decisão não pode desconsiderar tais resultados, devendo, portanto, indispensavelmente, contemplá-los na opção pública, sobretudo quando esta for contrária à vontade popular. Em outras palavras, a despeito da manifesta contrariedade da população afetada pelo empreendimento objeto de licenciamento ambiental, pode a Administração Pública autorizar a execução deste, caso motive sua decisão, contemplando todos os resultados da audiência pública, sob pena de violar os fundamentos básicos do Estado DemocráticoParticipativo.

Seria cumprimento de mera formalidade a realização de audiência pública, quando a decisão lá tomada não se preocupasse em reconhecer, valorizar e absorver os argumentos da população envolvida e atingida pelos significativos impactos do projeto - que não se limitam aos aspectos ambientais, abrangendo também o meio social, econômico e cultural.

Conclui-se que o instituto da audiência pública é um instrumento administrativo necessário à formulação da escolha pública sobre a autorização de empreendimento potencialmente poluidor, cujo objetivo primeiro é servir de canal direto de comunicação entre o administrador e a sociedade para que esta, sendo informada, possa se manifestar e fornecer subsídios para que o Poder Público decida fundado na legitimidade popular.

O quarto aspecto da audiência pública que contribui para a sua relevância no licenciamento ambiental é o momento no qual ela ocorre neste procedimento.

Independente da natureza do processo decisório administrativo, para que a participação pública seja útil e eficiente é necessário que esta se dê no momento adequado, ou seja, na fase inicial do procedimento, pois como salienta Álvaro Valey Mirra:

Do contrário, se a possibilidade de intervenção da população for aberta apenas em momento adiantado ou no fim do processo decisório, ou quando a decisão já tiver sido tomada, não se poderá falar em autêntica participação pública 
ambiental; haverá, então, mero artifício para legitimação popular da decisão, desde o inicio tida como certa e inafastável. ${ }^{167}$

(grifo nosso)

Partindo desta premissa, no que tange ao licenciamento ambiental, a participação pública deve ser efetivada em estágio precoce, vale dizer, no seu início, já que nesta etapa, em tese, todas as possibilidades de opções e soluções estão abertas e a população tem capacidade de realmente influenciar no resultado do procedimento, o que, conforme explicitado é uma das finalidades da audiência pública.

Além da análise destes quatro aspectos que definem a relevância do instituto, segue-se um breve relato sobre outras importantes características da audiência pública no licenciamento ambiental.

Com relação à qualificação dos legitimados, enquanto evento público relacionado à defesa do meio ambiente - direito fundamental e bem difuso - na audiência pública é permitida a presença de qualquer pessoa, devendo esta ocorrer em local acessível aos interessados. ${ }^{168}$

Quanto ao número de audiências públicas, note-se que poderá haver mais de uma sobre o mesmo projeto, devido à localização geográfica dos solicitantes e da complexidade do tema. ${ }^{169}$ Vale frisar que, diante da constatação de deficiências ${ }^{170}$ no EIA, a audiência pública poderá ser

\footnotetext{
${ }^{167}$ MIRRA, Álvaro Luiz Valery. Participação, processo civil e defesa do meio ambiente.p. $156 \mathrm{e}$ 157.

${ }^{168}$ Art. $2^{\circ}, \S^{\circ}$ da Resolução CONAMA n. 09/87.

169 Art. $2^{\circ} \S 5^{\circ}$ da Resolução CONAMA n. 09/87.

${ }^{170}$ Os arts. $5^{\circ}$ e $6^{\circ}$ da Resolução CONAMA n. 01/86, de fato, contém uma série de parâmetros que devem nortear a realização do Estudo de Impacto Ambiental, como as alternativas de localização do projeto, os impactos na implantação e operação da atividade, a delimitação da área impactada pelo empreendimento e a consideração dos projetos governamentais previstos ou implementados. Para isto, a norma estabelece que o EIA deverá ser integrado pelas atividades de diagnóstico ambiental da área de influência do projeto, contendo o levantamento dos recursos ambientais antes do empreendimento (meios físico, biológico, sócio-econômico); de análise dos impactos ambientais do projeto e suas alternativas, com a projeção das prováveis alterações relevantes; das medidas mitigadoras dos impactos negativos; e da elaboração de programa de acompanhamento e monitoramento de tais impactos. Tratando-se de estudo ambiental necessário à concessão da Licença Ambiental apenas Prévia, entretanto, não se exige que tais estudos sejam exaurientes, infensos a modificações, detalhamentos e complementações mesmo posteriores à concessão da licença. (...)

A constatação de deficiências no estudo ambiental prévio determina que, caso procedentes e relevantes tais incompletudes, os estudos deverão ser acrescidos, complementados ou esclarecidos, no bojo do licenciamento ambiental e não completamente reelaborados, desconsiderando-se in totum o EIA inicialmente trazido ao órgão ambiental. Admitir a conclusão contrária é admitir que haverá, no curso do licenciamento ambiental, diversas reelaborações completas dos EIA's e
} 
repetida quantas vezes forem necessárias e, sanados tais incompletudes, os interessados terão a possibilidade de comentar o mérito ou a fundamentação do EIA em nova audiência.

No que se refere ao anúncio na imprensa local sobre a convocação da audiência pública pelo órgão ambiental competente, atenta-se ao entendimento de Paulo Affonso Leme Machado no sentido de que o termo imprensa local abrange as diversas localidades impactadas pelo projeto, devendo, em todas, serem publicados os editais de convocação do evento. ${ }^{171}$

Desta forma, defende o autor que se somente fosse feita uma publicação do edital haveria afronta aos propósitos da própria resolução e do texto constitucional que, em suas palavras "é abrir a oportunidade de participação para todos os possíveis atingidos pelos efeitos do projeto, que potencialmente causará significativo impacto ambiental". ${ }^{172}$

No que tange à publicidade do EIA e sua disponibilidade para consulta pela população, o mesmo doutrinador leciona que:

(...) é preciso que se estabeleçam regras indicando quantos exemplares dos EPIAS/RIMAS ficarão disponíveis para consulta, a possibilidade dos exemplares serem ou não retirados para a extração de cópias, o local ou locais e horários de consulta. A ausência destes pormenores pode conduzir ao fracasso da audiência, que lamentavelmente, sempre será tentado pelos que - de modo franco ou subreptício - destroem ou querem destruir o meio ambiente. ${ }^{173}$

No que concerne à direção da audiência pública, será esta realizada pelo representante do órgão licenciador que abrirá as discussões com os interessados presentes após a exposição objetiva do projeto e de seu respectivo EIA. ${ }^{174}$ Faz-se mister mencionar que na exposição objetiva, aquele que "expõe, investiga ou critica, baseia-se nos fatos e não nos

nulidade das licenças já concedidas, uma para cada oportunidade de esclarecimentos e saneamento de deficiências, o que comprometeria, de forma definitiva, a necessária efetividade da atuação administrativa no licenciamento ambiental. Deve a legislação ambiental ser interpretada conforme os fins a que se destina: compatibilizar a proteção ao meio ambiente com a execução de obras necessárias ao desenvolvimento econômico e social do País, colocando-se o poder de polícia do Estado como filtro a condicionar e mesmo restringir, caso necessário, a alteração material do ambiente. TRF4 - APELAÇÃO CIVEL: AC 3801 RS 2006.71.01.003801-8. Relator(a): CARLOS EDUARDO THOMPSON FLORES LENZ. Julgamento: 13/10/2009. Órgão Julgador: TERCEIRA TURMA. Publicação: D.E. 04/11/2009.

${ }^{171}$ MACHADO, Paulo Affonso Leme. Direito Ambiental Brasileiro. p. 305.

${ }^{172}$ MACHADO, Paulo Affonso Leme. Direito Ambiental Brasileiro. p. 305.

${ }^{173}$ MACHADO, Paulo Affonso Leme. Direito Ambiental Brasileiro. p. 305. 
sentimentos", ${ }^{175}$ ou seja, é isento de parcialidade. Assim, na audiência pública o expositor é objetivo, não se posicionando nem contra, nem a favor do projeto e de seu respectivo EIA.

Sobre a exposição da atividade ou empreendimento, salienta-se que, apesar da aludida resolução não prever que esta seja feita por parte da equipe multidisciplinar, do empreendedor ou do proponente do projeto, não estão estes impedidos de fazê-lo.

A respeito da ata da audiência e juntada de documentação, a legislação prevê a lavratura de uma ata sucinta ao fim da audiência pública.176 Vale salientar que a concisão desta ata não pode excluir a demonstração das posições, protestos e demandas das pessoas que se pronunciaram, assim como não pode omitir os incidentes porventura ocorridos na sessão, sob pena de prejudicar sua veracidade e legitimidade. Pelo mesmo motivo, todos os documentos deverão ser assinados e anexados à ata. ${ }^{177}$

Quanto à fase de esclarecimentos sobre o EIA, vale notar que a dinâmica é a seguinte: os esclarecimentos que foram apresentados nas audiências serão transformados em solicitações a serem expostas ao empreendedor que, por sua vez, responderá ao que foi solicitado, providenciando as devidas alterações ao EIA em questão (art. 10, V e VI, respectivamente).

Conclui-se que, na legislação analisada, apesar de ser possível verificar previsões acerca da necessidade de interação entre as partes presentes na audiência pública, o êxito do licenciamento ambiental, como instrumento de prevenção de danos ambientais, depende do espaço aberto

\footnotetext{
${ }^{174}$ Art. $3^{\circ}$ da Resolução CONAMA n. 09/87.

175 Disponível em: <http://www.dicionariodoaurelio.com/Objetivo.html>. Acesso em: 15.mai.2013.

${ }^{176}$ Art. $4^{\circ}$ da Resolução CONAMA n. 09/87.

177 Neste sentido, a Lei 9.784/99 que versa sobre o procedimento administrativo em âmbito federal, prescreve em seu artigo 34 que "os resultados da consulta e da Audiência Pública e de outros meios de participação de administrados deverão ser apresentados com indicação do procedimento adotado".
} 
pela Administração Pública para a efetiva participação da sociedade neste procedimento.

Assim, ao efetivamente ser um mecanismo de empoderamento social, a audiência pública cumprirá sua finalidade. Em outras palavras, caso a audiência pública seja vista como mero canal de informação entre o empreendedor, o Poder Público e a população interessada, não se estará diante de participação pública efetiva, visto que sua característica essencial é precisamente a transferência de poder feita à população por meio da incorporação de sua vontade na decisão pública no âmbito do licenciamento ambiental.

A seguir, se analisará as audiências públicas em licenciamentos ambientais no âmbito do Estado do Rio de Janeiro.

\subsubsection{Audiências públicas em licenciamentos ambientais no Estado do Rio de Janeiro}

Considerando que o presente trabalho tem como objetivo versar sobre a participação popular e o acesso à informação em audiências públicas no bojo de licenciamentos ambientais no Estado do Rio de Janeiro, cumpre ressaltar a norma estadual específica sobre este tema, qual seja, a Resolução do Conselho Estadual de Meio Ambiente (CONEMA) n. 35/11.

Destaca-se que, diferentemente da legislação federal que abre espaço para a discricionariedade do órgão licenciador quanto à decisão sobre a realização de audiência pública em licenciamentos ambientais, esta norma estadual prevê que a audiência pública é de realização obrigatória por parte do órgão estadual competente para o licenciamento ambiental de atividades sujeitas ao EIA. ${ }^{178}$

Entretanto, a norma não restringe as audiências públicas aos licenciamentos ambientais de atividades ou empreendimentos sujeitos ao EIA. Assim, pode a Comissão Estadual de Controle Ambiental (CECA)

\footnotetext{
${ }^{178}$ Arts. $1^{\circ}$, caput, e $3^{\circ}$, caput, da Resolução CONEMA n. 35/11.
} 
determinar, mediante o requerimento fundamentado de interessados ou espontaneamente, a realização de audiência pública ou, inclusive, "realizála para a discussão de outros empreendimentos, obras ou atividades, assim como de programas, diretrizes, projetos e planos governamentais", tal como exposto no $\S^{\circ}$ do artigo $3^{\circ}$ da Resolução CONEMA n. 35/11.

Ademais, esta Resolução é aplicável, no que couber, para:

A realização de Reuniões Técnicas Informativas - RTI, conforme legislação e regulamentação própria, para o licenciamento ambiental de empreendimentos, obras ou atividades sujeitas a Relatório Ambiental Simplificado - RAS ou outras formas simplificadas de licenciamento ambiental ou, ainda, a critério do órgão ambiental, para subsidiar a elaboração de termos de referência. ${ }^{179}$

Cumpre destacar que o texto da referida Resolução do CONEMA, em seus considerandos, afirma a necessidade de empoderamento popular e de acesso à informação como instrumentos indispensáveis à realização de um licenciamento ambiental adequado e, em última instância, à tutela ambiental efetiva. Inclusive, tal norma faz referência expressa à já aludida Convenção de Aahrus. Vejamos:
CONSIDERANDO:
(...)
- que, para exercerem seu direito fundamental de viver em um ambiente sadio, os cidadãos devem ter acesso à informação, poder participar do processo de tomada de decisão, ter acesso à justiça ambiental, sendo necessárias medidas do Estado para assegurar e estimular esses direitos,
- que, em matéria ambiental, melhores oportunidades de acesso à informação e participação pública aumentam a qualidade da implementação de decisões, contribuem para o envolvimento público em questões ambientais, dão ao público oportunidade de exprimir seus questionamentos e permitem às autoridades públicas responder de maneira correspondente,
- o dever de transparência e publicidade em todos os poderes do Estado, assim como a virtude de um fortalecimento de legitimidade nas decisões governamentais na área ambiental,
- a importância do uso de instrumentos de comunicação, inclusive eletrônicos, assim como outras formas de comunicação,
- que a melhoria do acesso do público à informação e a sua mais ampla participação nos processos de tomada de decisões são ferramentas essenciais para garantir a sensibilização da população para as questões ambientais e promover uma melhor aplicação da legislação ambiental, contribuindo para reforçar e tornar mais eficazes as políticas de proteção do ambiente,
- a necessidade e a utilidade de realização de Audiências Públicas, como etapa do processo de licenciamento ambiental de atividades sujeitas a Estudo de Impacto Ambiental - EIA e respectivo Relatório de Impacto Ambiental - RIMA, como instrumento para alcançar os objetivos acima indicados,

${ }^{179}$ Art. $3^{\circ}, \S 2^{\circ}$, da Resolução CONEMA n. 35/11. 
(...)

- as demais finalidades e fundamentos da Convenção de Aarhus sobre Acesso à Informação, Participação do Público no Processo de Tomada de Decisão e Acesso à Justiça em Matéria de Ambiente,

(...)

(grifo nosso)

A resolução afirma, em suas finalidades e objetivos, que a audiência pública destina-se a fomentar e permitir a participação pública das comunidades interessadas, e que suas finalidades específicas são as seguintes: ${ }^{180}$

a) dar transparência e maior publicidade ao processo de licenciamento ambiental;

b) expor os dados e as informações relevantes em relação ao empreendimento, no que tange às características do empreendimento, alternativas tecnológicas e locacionais, diagnóstico ambiental, extensão e magnitude dos impactos ambientais, medidas mitigadoras e compensatórias, programas ambientais e impactos cumulativos e sinérgicos;

c) obter o conhecimento de fatos locais e tradicionais à comunidade afetada pelo empreendimento que possam ser úteis à decisão final do processo de licenciamento e à imposição de condicionantes a eventual licença concedida;

d) recolher sugestões, críticas e comentários que serão registrados e analisados no processo de licenciamento ambiental.

A norma estadual claramente reconhece que, para conferir força e legitimidade à decisão pública ambiental, faz-se necessária a transferência de poder e de informação idônea à sociedade civil. Em outras palavras, pode-se afirmar que a audiência pública é um meio de influência da população nas decisões do Poder Público em matéria ambiental.

Em conclusão, percebe-se que, no geral, a legislação estadual está em conformidade com a essência da audiência pública no âmbito e em função do licenciamento ambiental, como um instrumento democrático que visa a proteção e preservação do meio ambiente estadual. Deve-se analisar,

${ }^{180}$ Art. $2^{\text {o }}$, caput, e incisos da Resolução CONEMA n. 35/11. 
contudo, se a sua aplicação está sendo feita de forma adequada, o que se tentará fazer parcialmente ao analisar o caso da participação no licenciamento ambiental da Linha 4 do metrô do Rio de Janeiro. 


\section{A Linha 4 do metrô do Rio de Janeiro: breve análise da participação nas audiências públicas realizadas no licenciamento ambiental}

Uma vez apresentada a fundamentação legal sobre a relevância da participação pública e do acesso à informação no âmbito da audiência pública em licenciamento ambiental, neste trabalho propõe-se realizar uma análise crítica da participação no licenciamento da Linha 4 do Metrô do Rio de Janeiro.

\subsection{Breve histórico do licenciamento ambiental da Linha 4 do metrô do Rio de Janeiro}

Neste capítulo, apresenta-se um breve histórico deste licenciamento ambiental, das intervenções do Ministério Público. ${ }^{181}$

A Concessionária Rio Barra S/A é a responsável pelo projeto da Linha 4 do metrô que, com 14 quilômetros de extensão, visa fazer a ligação entre as zonas Oeste e Sul do Município Rio de Janeiro, conectando o Jardim Oceânico (Barra da Tijuca) a já existente estação General Osório, (Ipanema), sendo este empreendimento dividido em dois trechos: Oeste e Sul.

O primeiro vai do Jardim Oceânico à Gávea, já possui todas as licenças ambientais e de execução, tendo suas obras iniciadas em junho de 2010. Já o segundo trecho, objeto do licenciamento em questão, se inicia na Gávea, por meio de um túnel subterrâneo, e vai até a estação General Osório, onde a Linha 4 se conectará com as já existentes Linhas 1 e 2. O trecho Sul tem 5,7 quilômetros de extensão e compreende as estações Nossa

\footnotetext{
${ }^{181}$ Todas as informações sobre o histórico e documentos do licenciamento ambiental da Linha 4 do Metrô do Rio de Janeiro foram obtidas no site do Programa Rede Ambiente Participativo (RAP) - portal institucional criado pelo Ministério Público (MP) para ampliar o acesso à informação e propiciar meios de participação pública na avaliação dos impactos ambientais. Disponível em: http://rap.gov.br/?p=88 >. Acesso em: 20.mai.2013.
} 
Senhora da Paz (Ipanema), Antero de Quental e Jardim de Alah (ambas no Leblon).

Ao todo, o empreendimento prevê a construção de seis novas estações de metrô: Nossa Senhora da Paz, Antero de Quental, Jardim de Alah, Gávea, São Conrado e Jardim Oceânico.

Em 26 de maio de 2011 a Concessionária Rio Barra S/A apresentou ao órgão licenciador competente, qual seja, o Instituto Estadual do Ambiente (INEA/RJ), o requerimento de Licença Prévia (LP) para as obras da interligação da Linha 4 (Barra da Tijuca) com o sistema metroviário da cidade do Rio de Janeiro em operação. A proposta apresentada pela Concessionária versa sobre a interligação da Linha 4 (Etapa I - Barra da Tijuca) com a Linha 1, compreendendo o trecho que se inicia na Estação General Osório, passando pelas estações Nossa Senhora da Paz, Jardim de Alah e Antero de Quental, até se conectar no trecho entre a estação São Conrado e Gávea.

Desta forma, com o processo n. E-07/505.081/2011 foi iniciado administrativamente o procedimento de licenciamento ambiental da Linha 4 do Metrô.

Em seguida, o INEA/RJ emitiu a Instrução Técnica n.18/2011 com o objetivo de orientar a elaboração EIA e de seu respectivo RIMA.

Entendendo ter havido violações no bojo do licenciamento ambiental e antes mesmo da apresentação do EIA/RIMA ${ }^{182}$ ao INEA por parte do empreendedor, a $1^{\text {a }}$ Promotoria de Tutela Coletiva de Meio Ambiente e Patrimônio Cultural da Capital (MPRJ) ajuizou a ação civil pública (ACP) n. 0386458-56.2011.8.19.0001, com pedido liminar, protocolada no dia 01 de novembro de $2011 .^{183}$

\footnotetext{
${ }^{182}$ A empresa AGRAR Consultoria e Estudos Técnicos Ltda é a responsável pela elaboração do EIA/RIMA. Este documento está disponível em: $<$ http://pweb01.mp.rj.gov.br/Arquivos/RAP/EIA_linha4.pdf>. Acesso em: 12.jun.2013.

183 A petição inicial da ACP está disponível em: < https://docs.google.com/file/d/0BxSgcH3QIaqxM2MyOThhZGMtYjNiNS00MmZkLWJhNDgtY2 IwYmVmODRkNjlm/edit?pli=1> . Acesso: 20.mai.2013.
} 
Na exordial o MPRJ pleiteou, principalmente, que o Poder Judiciário suspendesse as obras da Linha 4 - entretanto já iniciadas - até a conclusão total do procedimento de licenciamento ambiental. Além disso, a ACP pediu que fosse apresentado o projeto completo desta linha à sociedade, o que à época ainda não tinha sido feito.

Ressalta-se que o maior descontentamento alegado pelo MPRJ se pautou no descarte de mais de $50 \%$ do traçado original, que faz parte do projeto já licitado, licenciado e aprovado pela população em 1998. Este previa a ligação da Barra da Tijuca à Linha 1 por meio das seguintes estações: Jardim Oceânico, São Conrado, Gávea, Jóquei (Jardim Botânico), Humaitá e Morro de São João (Botafogo). Entretanto, segundo o MPRJ, o projeto em execução prevê nova configuração, colocando em risco a eficiência e segurança futura do próprio sistema metroviário carioca.

Por isso, nesta ACP também foi requerida a execução da obra da Estação Gávea em dois níveis distintos, de forma a permitir a futura ligação da Barra com o Centro, da Zona Sul com a Barra, da Tijuca com a Zona Sul (por meio da Estação Uruguaiana) e do Centro com os bairros de Botafogo, Humaitá, Jardim Botânico e Lagoa.

Em 01 de dezembro de 2011, um mês após o ajuizamento da ACP, foi apresentado ao INEA o EIA/RIMA que, por sua vez, expõe como principais impactos positivos a geração de emprego e renda, dinamização da economia regional e melhoria nas condições e na oferta do transporte urbano. No que diz respeito aos impactos negativos da implementação deste empreendimento a geração de conflitos e tensões sociais, deslocamento de estabelecimentos comerciais, perda de áreas de uso, bens materiais e simbólicos, risco de acidentes com a população, alterações nos fluxos de trânsito e no sistema viário, perda de empregos, renda e arrecadação fiscal, alteração da dinâmica e dos usos locais, desocupação temporária, interferência sobre a paisagem local e bens culturais protegidos, pressão adicional de demanda da Linha 4 sobre as Linhas existentes e alteração da paisagem. 
Contudo, apesar do empenho do MPRJ no cumprimento de seu dever de buscar a tutela jurisdicional adequada para satisfazer aos interesses da coletividade, no dia 14 de dezembro de 2011, o requerimento de liminar foi indeferido pelo juiz da $15^{\text {a }}$ Vara de Fazenda Pública da Capital do Estado do Rio de Janeiro, e também pela $4{ }^{\mathrm{a}}$ Câmara Cível. Ambos entenderam que restaram ausentes os requisitos para o deferimento da medida pleiteada.

No entanto, faz-se necessário frisar, que na decisão de primeira instância afirmou-se que "restou incontroverso que houve alteração no projeto original por opção da Administração Pública no exercício do poder discricionário". ${ }^{184}$ Desta forma, percebe-se claramente que o próprio Poder Judiciário reconhece que foram feitas alterações no projeto original e neste trabalho entende-se que não foi devidamente licenciado o novo projeto antes do início de sua execução.

Ademais, a referida decisão implicitamente condicionou que fosse constatada a existência de dano para que, na hipótese de alteração significativa do projeto, fosse determinada a correção e/ou complementação do estudo e a nova análise pelo órgão ambiental competente. Todavia, vale ressaltar que a natureza da medida liminar é precisamente a de instrumento preventivo, sendo imprópria qualquer exigência de comprovação de dano como condição para o seu deferimento.

Na seqüência, o Grupo de Apoio Técnico Especializado (GATE) do MPRJ o analisou técnica e juridicamente o EIA/RIMA apresentado e elaborou o Parecer Técnico n. 01/2012, visando contribuir junto ao procedimento de licenciamento ambiental, bem como, fornecer elementos técnicos para instrução processual da referida ACP.

Este parecer técnico, apresentado em 12 de janeiro de 2012, aponta falhas no cumprimento de normas legais e de conteúdo do EIA/RIMA, em especial: (i) falta de uma efetiva análise comparativa entre as alternativas de traçado, deixando de atender o próprio Termo de Referência; (ii) 
justificativas do projeto deficientes; (iii) falta de compatibilidade do projeto com planos e programas governamentais; (iv) que os impactos tidos como positivos pelo EIA - "valorização imobiliária" e "dinamização da economia local" - são, na realidade, conflitantes com o planejamento urbano dos bairros atravessados; e (v) que o impacto positivo "melhoria na oferta de transporte" representaria, tal como proposto, uma pressão nas linhas existentes que apontam para a saturação do sistema em curto prazo. ${ }^{185}$

Dessa forma, conclui o referido parecer que se o EIA restar "inalterado ou não for complementado", inviabilizar-se-á "uma decisão válida sobre o licenciamento", ${ }^{186}$ visto que não houve uma correta avaliação dos diversos impactos socioambientais e econômicos do projeto.

Não obstante, a Administração Pública Estadual deu seguimento ao procedimento de licenciamento ambiental, convocando a sociedade civil para duas audiências públicas, que se realizaram nos dias 13 e 27 de fevereiro de 2012 - a seguir analisadas -, sendo que na segunda foi questionada a falta de acesso estudo de demanda feito pela FGV Projetos, o qual teria justificado a alternativa de traçado preferida pelo empreendedor como a melhor. ${ }^{187}$

Em resposta, no dia 01 de março de 2012, o INEA disponibilizou o referido estudo de demanda, ${ }^{188}$ complementando o EIA/RIMA apresentado pelo empreendedor. Novamente, o MPRJ questionou a validade dos

\footnotetext{
${ }^{184} \mathrm{~A}$ decisão judicial na íntegra está disponível em: $<$ ttp://srv85.tjrj.jus.br/ConsultaDocGedWeb/faces/ResourceLoader.jsp?idDocumento=000458CF03 481D64753066F1BDE2B4C95AF3BBC435421E2E >. Acesso em: 20. mai.2013

$185 \quad$ Disponível em: https://docs.google.com/file/d/0BxSgcH3QIaqxRIFjVHIENDIRUC0zSU5LT2s4ZGJzQQ/edit?pli $\frac{=1}{186}$. Acesso em: 03.jun.2013.

${ }_{186}$ Disponível em: https://docs.google.com/file/d/0BxSgcH3QIaqxRIFjVHIENDIRUC0zSU5LT2s4ZGJzQQ/edit?pli $=1$. Acesso em: 03.jun.2013.

${ }^{187}$ Note-se que as datas escolhidas para a realização das audiências públicas do licenciamento da Linha 4 do metrô do Rio de Janeiro (13.02.12 e 27.02.12) coincidem com a semana anterior e a seguinte ao feriado de Carnaval - período no qual a maioria da população da cidade do Rio de Janeiro está atenta as atividades deste evento. 188

Disponível em: $<$ https://docs.google.com/file/d/0BxSgcH3QIaqxRllKVWZBWktCUXM/edit?pli=1>. Acesso em: 03.jun.2013.
} 
documentos apresentados, afirmando que estes não correspondem integralmente ao trabalho feito pela FGV Projetos.

Na seqüência, em 16 de março de 2012 o MPRJ interpôs recurso de agravo de instrumento n. 0014582-83.2012.8.19.0000, ${ }^{189}$ requerendo, mais uma vez, a suspensão das obras em execução antes da conclusão do licenciamento ambiental. Em 27 de junho do mesmo ano, a 4a Câmara Cível negou o provimento deste recurso.

A CECA, em 27 de abril de2012, deliberou no sentido da expedição da Licença Prévia (Deliberação CECA n. $5483^{190}$ ), que foi concedida em 04 de maio de 2012, atestando a viabilidade socioambiental do empreendimento (LP IN019552) ${ }^{191}$.

Em 17 de maio de 2012, o GATE/MPRJ apresentou o Parecer Técnico-Jurídico n. 03/2012, ${ }^{192}$ contendo a análise final do EIA, considerando os Pareceres Técnicos do GATE/MPRJ, Pareceres do INEA, documentos complementares ao EIA/RIMA apresentados pelo empreendedor, Deliberação CECA n. 5483 e a LP IN019552. Concluiu-se pelo descumprimento do requisitos normativos obrigatórios, de conteúdo e procedimento do licenciamento ambiental. As principais observações do GATE/MPRJ são: restrição de publicidade e participação pública, falta de fundamentação adequada sobre as questões ambientais relevantes, além de incorreções quanto à previsão e avaliação dos impactos viários e ao patrimônio histórico e cultural.

Apesar da manifesta contrariedade da sociedade civil presente em audiências públicas, das análises do GATE/MPRJ sobre a debilidade do EIA/RIMA e dos esforços processuais do MPRJ, em 26 de junho de 2012

https://docs.google.com/file/d/0BxSgcH3QIaqxTjBILUR2TzFTN0NQSURHMU0zZzUyUQ/edit? pli=1>. Acesso em:

${ }_{190}$ Disponível em:https://docs.google.com/file/d/0BxSgcH3QIaqxT1FnNlhrMkJOT2s/edit?pli=1. Acesso em: 03.jun.2013.

https://docs.google.com/file/d/0BxSgcH3QIaqxNDRhNW9ybnFWT3M/edit?pli=1. Acesso em: 03.jun.2013. 
foi emitida a Licença de Instalação (LI IN019999) ${ }^{193}$ da Linha 4 do metrô do Rio de Janeiro.

\subsection{Análise crítica das audiências públicas}

Neste momento serão analisadas as duas audiências públicas sob a ótica da participação popular e do acesso à informação em matéria ambiental. Para tal, estudou-se os três instrumentos produzidos em decorrência de cada uma das audiências, quais sejam (i) a ata, (ii) a transcrição, e (iii) vídeo, todos produzidos pelo próprio órgão licenciador.

Ambas as audiências foram presididas pela Comissão Estadual de Controle Ambiental (CECA), ${ }^{194}$ da Secretaria de Estado do Ambiente do Estado do Rio de Janeiro (SEA), com o fito de apresentar à população e discutir com ela o RIMA do trecho Sul do empreendimento.

Em 13 de fevereiro de 2012 ocorreu a primeira audiência pública no Complexo Esportivo da Rocinha, no bairro de São Conrado, que contou com a participação de várias associações de moradores, vereadores, deputados, membros do INEA, da CECA e representantes do empreendedor, e cuja duração foi superior a 5 horas.

O projeto apresentado neste evento foi extremamente criticado pela sociedade civil que afirma não se tratar propriamente de uma Linha 4, uma vez que seria apenas a expansão da Linha 1 do metrô. Além disso, argumentou-se que apesar de sua construção ser mais simples e barata, o Poder Público optou por manter o novo traçado, sob a justificativa de que

$192 \quad$ Disponível em: <

https://docs.google.com/file/d/0BxSgcH3QIaqxSTBScDBuX3pmMVU/edit?pli=1>. Acesso em: 03.jun.2013.

Disponível em: < https://docs.google.com/file/d/0BxSgcH3QIaqxRnkwYU13WG52VmM/edit?pli=1>. Acesso em: 03.jun.2013.

194 Sobre a CECA: "é o órgão colegiado vinculado diretamente à Secretaria de Estado do Ambiente (SEA) a quem cabe convocar a Audiência Pública após a conclusão, pelo INEA, da análise técnica do EIA". Retirado do site do INEA. Disponível em<: http://200.20.53.7/Ineaportal/Faq.aspx?ID=957C0F27-F8CD45DA-9CC1-997DE0B00075>.

Acesso em 10.jun.13. Ou seja, a CECA não é um órgão independente do governo, visto que está vinculada à SEA que, por sua vez, subordina-se à Casa Civil. 
mais usuários serão atendidos, recusando, entretanto, liberar os estudos e informações detalhadas que comprovam tal conclusão. ${ }^{195}$

Quanto à "ata sucinta" desta audiência, ${ }^{196}$ vale ressaltar que se trata de documento incompleto e confuso, visto que não contempla as reivindicações da sociedade civil que não foram respondidas no decorrer da audiência pública, somente retratando as que foram atendidas, de modo que pode conduzir o leitor a erro.

Assim sendo, neste trabalho entende-se que esta ata é inapta a informar a sociedade sobre os resultados desta audiência pública e que resta prejudicada a sua finalidade de dar acesso à informação idônea.

Neste passo, como tal ata é insuficiente para analisar esta audiência pública sob o prisma da participação popular, estudou-se os outros instrumentos de acesso às informações deste evento, quais sejam a transcrição e os vídeos ${ }^{197}$.

Inicialmente, verifica-se que a Administração Pública conduz a audiência pública como se seu objetivo único fosse expor aos presentes o projeto apresentado pelo empreendedor. ${ }^{198}$ Posteriormente, nota-se que a postura do Poder Público se transforma no sentido de que a participação da sociedade teria caráter deliberativo para aquele evento. ${ }^{199}$

\footnotetext{
${ }^{195}$ Informação obtida na transcrição da primeira audiência pública para o licenciamento ambiental da Linha 4 do Metrô. Disponóvel em: https://docs.google.com/file/d/0BxSgcH3QIaqxejBCM2JTUHdUVmFXSEotSEZneDRGUQ/edit? pli=1 >. Acesso em: 03.jun.2013.

196 A ata sucinta da primeira audiência pública está disponível em:< http://urutau.proderj.rj.gov.br/inea_imagens/downloads/audiencias_publicas/Ata_Sucinta_Linha 4 metro_Audiencia_1.pdf >. Acesso em: 05.jun.2013

${ }^{197}$ Informações obtidas no vídeo das audiências públicas estão disponíveis em: < http://www.inea.rj.gov.br/fma/atas_transcricoes.asp>. Acesso em: 03.jun.2013.

${ }^{198}$ Trecho da transcrição da primeira audiência pública -Fita 1:

Página 2, TC: 04:34:29 “Então o objetivo da audiência pública é apresentar o projeto".

Página 2, TC:05:26:05 "Então a dinâmica da audiência, inicialmente o INEA apresenta os procedimentos administrativos do processo até o momento dentro do INEA o Maurício vai apresentar. E depois, a equipe que representa o empreendedor vai mostrar o projeto e a empresa que fez o relatório de impacto ambiental vai apresentar aqui os aspectos positivos, negativos, enfim, vai apresentar aqui a questão ambiental". Disponível em: < https://docs.google.com/open?id=0BxSgcH3QIaqxejBCM2JTUHdUVmFXSEotSEZneDRGUQ> . Acesso em: 05.jun.2013.

199 Trecho da transcrição da primeira audiência pública - Fita 1:

Página 3, TC:05:26:05 "E em seguida nós abrimos aqui para discussões, comentários contribuições. Esse é o objetivo de uma Audiência Pública que é uma das etapas de licenciamento ambiental de empreendimento natureza. Certo?".
} 
Da análise dos documentos percebe-se que muitos questionamentos e reivindicações realizadas pela população no curso do evento não foram respondidas, ou, em alguns casos, foram atendidas apenas parcialmente. ${ }^{200}$ Vale ressaltar os pontos considerados mais relevantes para o presente estudo:

a) Não há qualquer resposta significativa, tanto da Administração Pública, quanto da Concessionária Rio Barra S/A, a respeito dos efeitos sinérgicos oriundos da alteração do projeto inicial para a configuração final do traçado metroviário definido pelo Governo do Estado;

b) Não foi dada publicidade, nem foi analisado pelo INEA, em sua integralidade, o estudo de demanda que justificou a alteração no traçado da Linha 4 - observa-se, inclusive, que teria havido uma tentativa do Poder Público de manter oculto o referido estudo, dada sua reiterada omissão diante da demanda popular para analisá-lo; ${ }^{201}$

c) Não foi desfeita a relação entre a alteração do traçado e a necessidade de atendimento ao público temporário de turistas em função da realização dos eventos de grande porte na cidade do Rio de Janeiro, pelo contrário, a atuação da Administração Pública reforçou esse entendimento; ${ }^{202} \mathrm{e}$

d) A despeito da informação sobre a aquisição de novos trens, não foi esclarecido como haverá a redução dos intervalos entre os veículos -

Página , TC: 13:40:03 - "Bom como eu falei, nós estamos na fase de licença prévia. É a fase, que nós estamos em discussão de audiência pública, nós vamos ter dez dias subseqüentes a esta audiência pública, para que vocês possam encaminhar mais manifestações. Mas como nós vamos ter uma outra audiência pública no dia 27, nós vamos ter ainda que aguardar mais 10 dias, após a audiência pública que vai ser realizada no dia 27 , para receber ainda as manifestações de todos vocês".

Disponível em:

https://docs.google.com/open?id=0BxSgcH3QIaqxejBCM2JTUHdUVmFXSEotSEZneDRGUQ> . Acesso em: 05.jun.2013.

${ }^{200}$ Os questionamentos a que o texto faz referência podem ser identificados na transcrição da audiência,dentre outros, às páginas: 33-35; 38; 41-43; 56-58; 59-60; 62-66; 70-71; 71-73; 76; 78; 80-81; 82-83.

201 Ver páginas 42 e 60 da transcrição da primeira audiência. Disponível em: < https://docs.google.com/open?id=0BxSgcH3QIaqxejBCM2JTUHdUVmFXSEotSEZneDRGUQ> . Acesso em: 05.jun.2013.

202 Ver páginas. 47-49 da transcrição da primeira audiência. Disponível em: < https://docs.google.com/open?id=0BxSgcH3QIaqxejBCM2JTUHdUVmFXSEotSEZneDRGUQ> . Acesso em: 05.jun.2013. 
mantida a devida segurança - com os novos gatilhos que estão previstos no novo traçado.

Além dos questionamentos técnicos não respondidos, outro exemplo da atuação do Poder Público que reforça o esvaziamento da audiência pública enquanto instrumento de empoderamento popular, pode ser extraído do próprio texto do edital da licitação ${ }^{203}$ que, nas palavras do SecretárioChefe da Casa Civil, afirma que a ligação entre a estação Gávea e a Linha 1 será definida conforme escolha da concessionária. Assim, perante esta afirmativa entende-se que já havia uma escolha do traçado pré-definida entre o empreendedor e o Poder Público, e que a participação popular em audiência pública não tinha o condão de influenciar nesta decisão (política) pública.

Portanto, não é defensável a hipótese de que a definição do traçado, de fato, considerou a opinião popular, assim como, não se pode afirmar que na primeira audiência pública houve a participação de uma sociedade devidamente informada - já que, conforme mencionado, o estudo de demanda não fora publicizado.

A segunda audiência pública foi realizada no dia 27 de fevereiro de 2012, na Escola André Maurois, no bairro da Gávea, com a presença de aproximadamente trezentas pessoas e com duração de cinco horas.

Nota-se que sua "ata sucinta", tal como a da primeira audiência, é instrumento incapaz de informar, adequadamente, a sociedade sobre o empreendimento em questão, visto que, novamente, houve supressão de informações essenciais que, também neste caso, podem conduzir o leitor a um entendimento equivocado sobre os resultados daquele evento. ${ }^{204}$

Sendo assim, mais uma vez, esse trabalho estudou a transcrição e os vídeos da segunda audiência como fontes para a análise dos níveis de

203 
participação popular e acesso à informação neste momento do licenciamento ambiental da Linha 4 do metrô.

Diferentemente da primeira audiência, os representantes do órgão ambiental apresentaram o evento como um espaço deliberativo. ${ }^{205}$ Contudo, os demais representantes do Poder Público não abriram espaço para qualquer manifestação efetivamente participativa. ${ }^{206}$

Entretanto, apesar da postura adotada pelos demais representantes do Poder Público, verificou-se um maior número de intervenções populares não só nos momentos previstos, como também por meio de vaias e saudações.

Vale ressaltar que o Ministério Público, que, por sua vez, não participou da primeira audiência, somente pode se manifestar após duas horas de apresentação do empreendimento por parte do Poder Público.

O promotor Carlos Frederico Saturnino criticou o projeto do Governo Estadual, principalmente pelo fato que não terem sido apresentados os motivos, constantes no estudo de demanda realizado pela FGV Projetos, que embasam a troca do traçado original pelo novo. Dentre as críticas do promotor, merecem destaque:

a) As diversas omissões no EIA/RIMA;

b) A ausência de justificativa técnica plausível para a alteração no traçado;

c) A incompatibilidade com o Plano Diretor de Transporte Urbano elaborado pelo próprio governo estadual; e

\footnotetext{
${ }^{205}$ Trecho da transcrição da segunda audiência pública - CD 1

Páginas 2 e 3, TC: 00 00' 27": "Conforme o doutor Gusmão falou na abertura da audiência pública. A audiência pública ela contem caráter decisório, deliberativo. Nós estamos com a fase do licenciamento. A fase do licenciamento prévio. E o objetivo da audiência pública é de recolher as manifestações de todos vocês aqui. Que são as pessoas diretamente envolvidas com o projeto. Ouvir os anseios de todos vocês, as manifestações em relação ao projeto, em relação ao estudo de impacto ambiental". Disponível em:< https://docs.google.com/file/d/0BxSgcH3QIaqxM1UzaHhQektTVVNCYnlJaTIyYUpNUQ/edit?pl $\mathrm{i}=1>$. Acesso em: 05.jun.2013.

${ }^{206}$ Ver as páginas $69-70 ; 75-76 ; 87$ da transcrição da segunda audiência. Vale destacar a fala do secretário-chefe da Casa Civil logo após as intervenções populares: "Alguns dos senhores e senhoras acham que outra opção é melhor. Nós do governo entendemos que essa opção que estamos pedindo o INEA pra licenciar é a mais correta. (...) Não cabe ao órgão ambiental decidir se o traçado vai ser por Leblon - Ipanema, ou vai ser pelo Jardim Botânico. Essa é uma decisão do governo". (grifo nosso). Disponível em:<
} 
d) A ausência de detalhamento sobre os cruzamentos (em Y e X) omitidos no curso da explanação do projeto. ${ }^{207}$

Assim como ocorrido na primeira audiência pública, diversos questionamentos ressaltados pelos participantes não foram respondidos, ou sequer considerados, pelo empreendedor e pelo Poder Público. ${ }^{208}$

Nesse passo, nota-se ter havido entre as duas audiências públicas alguma mudança de postura na condução do evento, visto que na segunda audiência os condutores permitiram que diversas intervenções da sociedade fossem seguidas umas das outras, sendo que todas as respostas dadas pelo Poder Público ocorreram em um único momento, de modo que se dificultou que todos os pontos levantados pelos participantes fossem devidamente contemplados.

Ainda acerca dos questionamentos levantados pelos participantes desta segunda audiência, merecem destaque os pedidos de acesso ao estudo de demanda - solicitação essa também realizada na primeira audiência. Embora o representante da empresa contratada para a realização do referido estudo estivesse presente no evento, a população e o MPRJ demandaram que fosse disponibilizado o documento em sua íntegra ${ }^{209}$ - como já mencionado, tal documento só foi disponibilizado em março de 2012.

Assim, a despeito da quantidade significativa de questionamentos não respondidos, a segunda audiência foi encerrada e tida como válida. Não obstante, considerando a necessidade de que esclarecimentos fossem prestados, a população presente solicitou a realização de uma terceira

\footnotetext{
https://docs.google.com/file/d/0BxSgcH3QIaqxM1UzaHhQektTVVNCYnlJaTIyYUpNUQ/edit?pl $\mathrm{i}=1$ >. Acesso em: 05.jun.2013.

207 Ver as páginas 34-40 da transcrição da segunda audiência. Disponível em:< https://docs.google.com/file/d/0BxSgcH3QIaqxM1UzaHhQektTVVNCYnlJaTIyYUpNUQ/edit?pl $\mathrm{i}=1>$. Acesso em: 05.jun.2013.

${ }^{208}$ Os questionamentos a que o texto faz referência podem ser identificados na transcrição da segunda audiência, dentre outras, nas páginas: $16 ; 18 ; 24 ; 44-45 ; 46-61$ (parte das questões levantadas); 62-66; 76-77; 92.

${ }^{209}$ Reiterando a ausência de transparência, destaca-se trecho da primeira reação do SecretárioChefe da Casa Civil após a solicitação de acesso a integra do estudo: “(...) Mas vocês querem todos os elementos? É muito papel...” Página 87 da transcrição da segunda audiência. Disponível em:<

https://docs.google.com/file/d/0BxSgcH3QIaqxM1UzaHhQektTVVNCYnlJaTIyYUpNUQ/edit?pl $\mathrm{i}=1$ >. Acesso em: 05.jun.2013.
} 
audiência pública. ${ }^{210}$ Esta hipótese foi imediatamente refutada pelo Secretário-Chefe da Casa Civil ${ }^{211}$ e o representante do órgão ambiental, por sua vez, na tentativa de solucionar o impasse, comprometeu-se a apresentar tal demanda em reunião do colegiado CECA - contudo, nenhuma manifestação da CECA a respeito da solicitação foi informada à população.

Desta maneira, após a realização das duas audiências públicas, o INEA deu seguimento ao licenciamento ambiental da Linha 4 do metrô do Rio de Janeiro, emitindo as licenças prévia e de instalação do empreendimento - conforme anteriormente mencionado.

Como é possível verificar a partir das licenças emitidas e das obras já em execução, parte significativa das solicitações e manifestações feitas nas audiências públicas não foi considerada pelo Poder Público na motivação de sua decisão.

Por tudo acima exposto, entende-se que a decisão pública sobre o licenciamento em questão não só é ilegal por vício de motivação, como também é ilegítima, visto que não possui respaldo na vontade popular manifestada em audiência pública.

Assim, conclui-se que tais audiências públicas não cumpriram com sua finalidade de permitir o acesso à informação idônea e a transferência de poder para que a população pudesse, de fato, participar de maneira informada na decisão sobre o empreendimento a ser licenciado, motivo pelo qual, deveriam ter sido anuladas.

\footnotetext{
210 Ver a página 67 da transcrição da segunda audiência. Disponível em:< https://docs.google.com/file/d/0BxSgcH3QIaqxM1UzaHhQektTVVNCYnlJaTIyYUpNUQ/edit?pl $\mathrm{i}=1>$. Acesso em: 05.jun.2013.

${ }^{211}$ Nesse sentido, destaca-se a fala do Secretário-Chefe da Casa Civil: "Veja quem compete decidir sobre audiências públicas? A CECA. Seu pedido já foi feito e foi anotado ali. Mas o estado não concorda com uma terceira audiência pública porque não é necessário" (grifo nosso). Ver a página $76 \mathrm{da}$ transcrição da segunda audiência pública. Disponível em:< https://docs.google.com/file/d/0BxSgcH3QIaqxM1UzaHhQektTVVNCYnlJaTIyYUpNUQ/edit?pl $\mathrm{i}=1$ >. Acesso em: 05.jun.2013.
} 


\section{Conclusão}

Como apresentado, entende-se que num regime democrático participativo não há como afastar a sociedade civil das decisões públicas e privadas suscetíveis de afetar o equilíbrio do meio ambiente, bem difuso, necessário à sadia qualidade de vida desta e das próximas gerações.

No plano internacional e nacional, a participação pública e o acesso à informação são plenamente reconhecidos como necessários e imprescindíveis à proteção do meio ambiente.

Assim, primeiramente, conclui-se pela indissociabilidade entre a participação popular, o acesso à informação e a proteção do meio ambiente.

$\mathrm{O}$ Direito Ambiental nacional confere legitimidade à população para atuar na tutela ambiental legislativa, administrativa e judicial, dispondo de valiosíssimas ferramentas de cidadania e controle social do Poder Público em matéria ambiental.

No que tange às normas brasileiras sobre o licenciamento ambiental de obras e atividades que impactam o meio ambiente, em âmbito federal. prevê-se o acesso à informação e a participação popular neste procedimento, tanto via comentários, quanto via audiências públicas - estas últimas dependentes do juízo de discricionariedade do órgão ambiental .

Neste aspecto, com base nos fundamentos do Estado DemocráticoParticipativo, na consagração do direito fundamental ao meio ambiente equilibrado, seu caráter difuso e a exigência constitucional de publicidade, entende-se ser obrigatória a convocação de audiências públicas no curso de licenciamentos ambientais, em âmbito federal, de obras e atividades que impactam significativamente o meio ambiente - para os quais se exige o prévio estudo de impacto ambiental.

Assim, ao definir que a população dispõe de capacidade para intervir em determinado processo decisório - como no caso das audiências públicas ambientais - entende-se que o legislador pátrio pretendeu que houvesse verdadeiro empoderamento social. Afinal, são limitadas e restritas as 
hipóteses em que a sociedade civil - autorizada pela lei - possui a capacidade legal de intrometer-se em decisões do Poder Executivo.

Desta forma, a realização de audiências públicas, com possibilidade de participação dos interessados, como também a publicidade do procedimento administrativo estão relacionados à legitimidade e legalidade das decisões do órgão licenciador e, portanto, seu esvaziamento e/ou manipulação atinge diretamente o Estado Democrático-Participativo.

Neste passo, caso o órgão ambiental se valha da audiência pública como mero canal de informação, não se estará diante de participação pública efetiva, visto que a característica essencial da audiência é o empoderamento da sociedade civil, que tem nestes eventos a real possibilidade de influenciar na decisão do órgão ambiental sobre a viabilidade do empreendimento a ser licenciado.

No caso concreto do licenciamento ambiental da Linha 4 do metrô do Rio de Janeiro, a partir da análise dos documentos publicizados, concluise que o instituto da audiência pública foi desmoralizado e esvaziado de sua finalidade e que não houve transparência do Poder Público no que diz respeito às informações sobre o empreendimento em questão.

Isso porque ambas as audiências serviram, essencialmente, como canais de informação e como veículos para que as insatisfações sociais fossem extravasadas - e recebidas com desprezo pelos executores do projeto e pelo Poder Público, cujos interesses já estavam pré-definidos. Em nenhum momento, inclusive quando da solicitação de nova audiência pública, foi possível verificar a transferência de qualquer capacidade decisória ou de influência da vontade popular na decisão (política) pública.

A despeito da manifesta contrariedade da população em relação à viabilidade da Linha 4 do metrô do Rio de Janeiro, entende-se que a Administração Pública podia ter autorizado a sua execução, desde que tivesse motivado adequadamente a sua decisão, contemplando todos os resultados das duas audiências públicas, o que, conforme analisado, não foi feito. 
Com base neste caso concreto, questiona-se se, de fato, o interesse público, alegado tantas vezes pelos representantes do Governo Estadual, correspondeu ao interesse manifestado pela população? E a audiência, foi pública ou publicada?

Desta forma, entende-se que o instituto da audiência pública foi elevado à mera condição de formalidade administrativa, ou seja, sua realização não estava comprometida com a garantia da cidadania e da democracia, mas tão somente com a burocracia do procedimento ambiental.

Por tudo acima exposto, conclui-se que foram violadas a Constituição Federal, a legislação infraconstitucional e a legislação estadual, de forma que as audiências públicas deveriam ser anuladas por vício de legalidade, assim como, consideradas irregulares as licenças ambientais expedidas para a implementação - ou continuação das obras da Linha 4 do metrô do Rio de Janeiro. 


\section{Bibliografia:}

ANTUNES, Paulo de Bessa. Direito Ambiental. 14ª ed. São Paulo: Editora Atlas, 2012. 1152p.

ARNSTEIN, Sherry R. A Ladder of Citizen Participation. In: Journal of the American Planning Association, Vol. 35, Issue 4. Nova York: Kraus Reprinting Corp, 1969.

AVRITZER, Leonardo. Sociedade Civil e Participação Social no Brasil.

Disponível

em <http://www.democraciaparticipativa.org/files/AvritzerSociedadeCivilParti cipacaoBrasil> Acesso em 16 abril. 2013.

BATISTA, Karla da Silva Costa. Verbete Audiência Pública. In: CASTRO, Carmem Lúcia Freitas de; GONTIJO, Cynthia Rúbia Braga; AMABILE, Antônio Eduardo de Noronha (orgs.) Dicionário de Políticas Públicas. Barbacena: Editora da Universida do Estado de Minas Gerais, 2012. 484p. Disponível em:

http://www.calameo.com/books/0016339049620b36a7dac>. Acesso em: 16.abr.2013.

BENJAMIN. Antônio Herman V. Dano ambiental: prevenção, reparação e repressão. São Paulo: Editora Revista dos Tribunais, 1993. 470p.

BONAVIDES, Paulo. Teoria constitucional da democracia participativa: por um direito constitucional de luta e resistência, por uma nova hermenêutica, por uma repolitização da legitimidade. São Paulo: Malheiros Ed., 2001.392p.

brasileiro. In: Revista de Direito Administrativo. Vol. 209. Rio de Janeiro: Editora FGV, 1997.

CANOTILHO, J. J. Gomes. Direito Constitucional. 6 ${ }^{\mathrm{a}}$ ed. Coimbra: Editora Almedina, 1993. 1194p.

CANOTILHO, José Joaquim Gomes; MORATO LEITE, José Rubens: Direito Constitucional Ambiental Brasileiro. $4^{\mathrm{a}}$ ed. São Paulo: Editora Saraiva, 2011.496p. 
DAL BOSCO, Maria Goretti. Audiência Pública como Direito de Participação. In: Revista dos Tribunais. Vol. 809. São Paulo: Editoria Revista dos Tribunais, 2003.

FENSTERSEIFER, Tiago. Direitos Fundamentais e Proteção do Ambiente. Porto Alegre: Livraria do Advogado, 2008. 306p.

FIGUEIREDO, Guilherme José Purvin de. Curso de Direito Ambiental. 5a ed rev., atual. e reform. São Paulo: Editora Revista dos Tribunais, 2012. $541 \mathrm{p}$.

FINK, Daniel Roberto. Audiência Pública em matéria ambiental no Direito brasileiro. In: Revista dos Tribunais. Vol. 695. São Paulo: Editora Revista dos Tribunais, 1993.

FREITAS, Vladimir Passos de. A Constituição Federal e a Efetividade das Normas Ambientais. $2^{\text {a }}$ ed., São Paulo, Editora Revista dos Tribunais, 2002. $246 \mathrm{p}$.

FURRIELA, Rachel Biderman. Democracia, cidadania e proteção ao meio ambiente. São Paulo: Annablume: Fapesp, 2002. 187p.

JUSTINO, Gustavo Henrique. Audiências públicas e o processo administrativo. In: Revista de Direito Administrativo. Vol. 209. Rio de Janeiro: Editora FGV, 1997.

KLIKSBERG, Bernardo. Falácias e mitos do desenvolvimento social. Tradução: VALENZUELA, Sandra Trabucco. São Paulo: Cortez Editora, 2001.

LEITE, José Rubens Morato. Ação popular - Um exercício da cidadania ambiental? In: Revista de Direito Ambiental 17/128, São Paulo. Editora Revista dos Tribunais, janeiro-março/2000.

MACHADO, Paulo Affonso Leme. Direito à informação e meio ambiente. São Paulo: Malheiros Editores, 2006. 288p.

MACHADO, Paulo Affonso Leme. Direito à informação e meio ambiente. São Paulo: Malheiros Editores, 2006. 288p

MACHADO, Paulo Affonso Leme. Direito Ambiental Brasileiro. $20^{\mathrm{a}}$ ed rev., atual. e ampl. São Paulo: Malheiros Editores, 2012. 1280p. 
MAZZUOLI, Valerio de Oliveira; AYALA, Patryck de Araújo. Cooperação internacional para a preservação do meio ambiente: o direito brasileiro e a Convenção de Aarhus. Rev. direito GV, São Paulo , v. 8, n. 1, Junho, 2012 . Disponível em $<$ http://www.scielo.br/scielo.php?script=sci_arttext\&pid=S1808243220120 00100012\&lng=en\&nrm=iso>. Acesso em 24 mar. 2013.

MEIRELLES, Hely Lopes. Direito Administrativo brasileiro. $23^{\mathrm{a}}$ ed., atual. São Paulo: Malheiros Editores, 1998.679p.

MELlo, Celso Antônio Bandeira de. Curso de Direito Administrativo. 28 ed. São Paulo: Malheiros, 2011, 1127p.

MILARÉ, Édis. Direito do Ambiente: a gestão em foco: doutrina, jurisprudência, glossário. $7^{\mathrm{a}}$ ed rev., atual. e reform. São Paulo: Editora Revista dos Tribunais, 2011. 1647p.

MIRRA, Álvaro Luiz Valery. Participação, processo civil e defesa do meio ambiente. $1^{a}$ ed. São Paulo: Editora Letras Jurídicas, 2011. 650p.

MORAES, Alexandre de. Direito Constitucional. 23 ${ }^{\mathrm{a}}$ ed. São Paulo: Editora Atlas, 2008.940p.

MOREIRA NETO, Diogo de Figueiredo. Audiências públicas. In: Revista de Direito Administrativo. Vol. 210. Rio de Janeiro: Editora FGV, 1997.

MOREIRA NETO, Diogo de Figueiredo. Direito da participação política legislativa, administrativa, judicial: fundamentos e técnicas constitucionais da democracia. Rio de Janeiro: Editora Renovar, 1992. 212p.

MORIN, Edgar. Introdução ao pensamento complexo. $4^{\mathrm{a}}$ ed. Porto Alegre: Editora Sulina, 2011. 120p.

NETO, Nicolao Dino de Castro e Costa. Proteção Jurídica do Meio Ambiente. São Paulo: Editora Del Rey, 2003.407p.

NOBRE JÚNIOR, Edilson Pereira. Função Administrativa e Participação Popular. In: Revista dos

SILVA, José Afonso da. Curso de Direito Constitucional Positivo. $31^{\mathrm{a}}$ ed. rev. atual. São Paulo: Editora Malheiros, 2008.926p. 
SILVA, José Afonso da. Direito Ambiental Constitucional. $7^{\mathrm{a}}$ ed., rev. e atual. São Paulo: Editora Malheiros, 2008.358p.

Silva-Sánchez, Solange. Cidadania ambiental: novos direitos no Brasil. São Paulo: Humanitas/FFLCH/USP, 2000. 220p.

Tribunais. Vol. 796. São Paulo: Editora Revista dos Tribunais, 2002 